\title{
THE
}

\section{Direct Observations of Along-Isopycnal Upwelling and Diapycnal Velocity at a Shelfbreak Front}

\author{
John A. Barth \\ Dave Hebert \\ University of Rhode Island \\ Andrew C. Dale \\ David S. Ullman \\ University of Rhode Island
}

Follow this and additional works at: https://digitalcommons.uri.edu/gsofacpubs

\section{Citation/Publisher Attribution}

Barth, J.A., D. Hebert, A.C. Dale, and D.S. Ullman, 2004: Direct Observations of Along-Isopycnal Upwelling and Diapycnal Velocity at a Shelfbreak Front. J. Phys. Oceanogr., 34, 543-565. doi: 10.1175/2514.1 Available at: https://doi.org/10.1175/2514.1

This Article is brought to you for free and open access by the Graduate School of Oceanography at DigitalCommons@URI. It has been accepted for inclusion in Graduate School of Oceanography Faculty Publications by an authorized administrator of DigitalCommons@URI. For more information, please contact digitalcommons-group@uri.edu. 


\title{
Direct Observations of Along-Isopycnal Upwelling and Diapycnal Velocity at a Shelfbreak Front*
}

\author{
JOHN A. BARTH \\ College of Oceanic and Atmospheric Sciences, Oregon State University, Corvallis, Oregon \\ DAVE HEBERT \\ Graduate School of Oceanography, University of Rhode Island, Narragansett, Rhode Island \\ AndRew C. DAle \\ College of Oceanic and Atmospheric Sciences, Oregon State University, Corvallis, Oregon \\ DAVID S. UlLman \\ Graduate School of Oceanography, University of Rhode Island, Narragansett, Rhode Island
}

(Manuscript received 18 November 2002, in final form 2 September 2003)

\begin{abstract}
By mapping the three-dimensional density field while simultaneously tracking a subsurface, isopycnal float, direct observations of upwelling along a shelfbreak front were made on the southern flank of Georges Bank. The thermohaline and bio-optical fields were mapped using a towed undulating vehicle, and horizontal velocity was measured with a shipboard acoustic Doppler current profiler. A subsurface isopycnal float capable of measuring diapycnal flow past the float was acoustically tracked from the ship. The float was released near the foot of the shelfbreak front (95-100-m isobath) and moved $15 \mathrm{~km}$ seaward as it rose from 80 to $50 \mathrm{~m}$ along the sloping frontal isopycnals over a 2-day deployment. The float's average westward velocity was $0.09 \mathrm{~m} \mathrm{~s}^{-1}$, while a drifter drogued at $15 \mathrm{~m}$ released at the same location moved westward essentially alongfront at $0.18 \mathrm{~m}$ $\mathrm{s}^{-1}$. The float measured strong downward vertical velocities (in excess of $0.02 \mathrm{~m} \mathrm{~s}^{-1}$ ) associated with propagation of internal tidal solibores in the onbank direction from their formation near the shelf break. The float measured large upward vertical velocities (in excess of $0.001 \mathrm{~m} \mathrm{~s}^{-1} \simeq 100 \mathrm{~m} \mathrm{day}^{-1}$ ) as the pycnocline rebounded adiabatically after the passage of the internal tide solibore. The directly measured mean along-isopycnal vertical velocity was $17.5 \mathrm{~m} \mathrm{day}^{-1}$. Intense mixing events lasting up to 2 hours were observed in the shelfbreak front at the boundary between cold, fresh shelf water and warm, salty slope water. Diapycnal velocities of up to 3 $\times 10^{-3} \mathrm{~m} \mathrm{~s}^{-1}$ were measured, implying a diapycnal thermal diffusivity as large as $10^{-2} \mathrm{~m}^{2} \mathrm{~s}^{-1}$, indicative of strong mixing events in this coastal front.
\end{abstract}

\section{Introduction}

Along-isopycnal motion can consist of two components. The stronger primary flow, often in geostrophic or nearly geostrophic balance with sloping frontal isopycnals, is normal to the pressure gradient. A weaker secondary circulation flowing in the plane at right angles to the primary flow may also exist. Near strong coastal ocean fronts, the secondary flow is usually at least an order of magnitude smaller that the primary flow, a few

* Global Ocean Ecosystem Dynamics Contribution Number 407.

Corresponding author address: Dr. John A. Barth, College of Oceanic and Atmospheric Sciences, Oregon State University, 104 Ocean Admin Bldg., Corvallis, OR 97331-5503.

E-mail: barth@coas.oregonstate.edu centimeters per second as compared with $0.1-1.0 \mathrm{~m} \mathrm{~s}^{-1}$. This makes measurement of the secondary flow very challenging with, for example, an Eulerian sampling technique like shipboard acoustic Doppler current profiling. Surface Lagrangian drifters or constant-pressure floats will also fail to follow the secondary circulation as it moves along sloping isopycnals.

The secondary flow, although weak, is important for the maintenance or degradation of the density structure associated with a coastal front and which supports the primary flow. The secondary circulation can also carry biological material (e.g., phytoplankton, suspended detritus, or sediment) and chemical properties (e.g., nutrients, trace metals) along the frontal interface even sometimes from regions of insufficient light for growth up into the euphotic zone.

In this paper, we report on the direct observation of 
secondary circulation near a shelfbreak front using a Lagrangian subsurface float. The time-varying, threedimensional subsurface hydrographic and velocity fields are sampled with high resolution using a towed undulating vehicle and a shipboard acoustic Doppler current profiler (ADCP), respectively. The results presented here are part of a larger effort to understand cross-front exchange on Georges Bank using a towed vehicle and floats both on the northern (Dale et al. 2003; Ullman et al. 2003) and southern flanks of the bank.

Previous studies have used tracers to infer the secondary circulation near a shelfbreak front. These include analysis of a purposeful dye release (Houghton and Visbeck 1998), tracking of a subsurface signature of suspended particles (Barth et al. 1998), and tracing of low stratification water from out of the bottom boundary layer (Pickart 2000). The latter two studies also used directly measured across-front convergent horizontal velocities to infer the vertical component of the secondary circulation. Estimates of the along-isopycnal vertical velocity on the shoreward side of the shelfbreak front south of Cape Cod in the Middle Atlantic Bight from the dye and suspended particle analyses range from 4 to $11 \mathrm{~m} \mathrm{day}^{-1}$. Pickart (2000) estimated an average upwelling velocity of $23 \mathrm{~m}^{\text {day }}{ }^{-1}$ by integrating the continuity equation and assuming that one-half of the cross-stream convergence upwelled while the other onehalf fed a growing alongstream flow due to isobath convergence.

Modeling studies predict the existence of along-isopycnal upwelling on the shoreward side of an idealized shelfbreak front (Gawarkiewicz and Chapman 1992; Chapman and Lentz 1994). Convergence in the bottom boundary layer due to reversal of the offshore Ekman transport accompanying the primary alongshore flow causes upwelling into the interior. Model predictions of $4 \mathrm{~m} \mathrm{day}^{-1}$ vertical velocity are in general agreement with the inferred flows from tracers.

We use a neutrally buoyant float to track water parcel motion near the shelfbreak front during June 1999 on the southern flank of Georges Bank. The float's position is determined acoustically and it measures pressure, temperature, and flow past the float, that is, the diapycnal velocity (details below). The three-dimensional hydrographic, bio-optical and velocity context for the float is provided by towing a SeaSoar near the subsurface float from a vessel equipped with a shipboard ADCP. D'Asaro (2003) used a subsurface isopycnal float to measure the vertical profiles of hydrographic (and, in some cases, bio-optical) properties by occasionally operating the float in a profiler mode. Our approach has the advantage that the isopycnal float stays with the water parcel, but with the added cost associated with measuring the subsurface vertical profiles from a ship. A particular water parcel may change its density through diapycnal mixing, a process which causes an isopycnal float to separate from the true water parcel trajectory, but we measure this deviation quantitatively (details below).

This paper is organized as follows. The measurement techniques and data analysis methods are described in the next section. Then results from a float deployment near a relatively straight, two-dimensional shelfbreak front are reported. The float and SeaSoar observations are used to describe the mean shelfbreak front and jet structure, the passage of internal tide solibores, and diapycnal and along-isopycnal mixing events. Then, this is contrasted with a second deployment when the front was considerably more three-dimensional. Last, a discussion and conclusion section follows.

\section{Data and analysis methods}

We used a combination of high-spatial resolution, three-dimensional mapping using a towed undulating vehicle, an acoustically tracked subsurface isopycnal float, and a satellite-tracked surface drifter to study the shelfbreak region on the southern flank of Georges Bank in June 1999.

\section{a. Three-dimensional mapping}

From 14 June to 1 July 1999, hydrographic and biooptical measurements were made from the towed undulating vehicle SeaSoar (Pollard 1986). SeaSoar was towed using a hydrographic cable and profiled from the sea surface to $110 \mathrm{~m}$ over deep water and to within 10 $\mathrm{m}$ of the bottom over the bank. Cycle time in deep water was about 6.5 minutes resulting in surface points being separated by $1.3 \mathrm{~km}$ at the ship's typical $7 \mathrm{kt}(3.6 \mathrm{~m}$ $\mathrm{s}^{-1}$ ) tow speed. Horizontal separation between profiles at middepth is half this value. Cycles over the shallow bank, 0-70-0 m, took 2 minutes, and so surface points were separated by $420 \mathrm{~m}$. Bottom avoidance was accomplished by using R/V Oceanus' 3.5-kHz Knudsen echosounder as input to the SeaSoar flight control software.

The SeaSoar was equipped with a Seabird $911+$ conductivity-temperature-depth (CTD) instrument with pumped, dual temperature-conductivity sensors pointing forward through the nose of SeaSoar. Details of how the CTD data are processed can be found in Barth et al. (2000b). Fluorescence was measured with a WETLabs FlashPak fluorometer (460-nm excitation, 695-nm emission) mounted on the upper tail fin of SeaSoar. For making horizontal maps and vertical sections, the measurements were first averaged vertically to 2-dbar bins and horizontally to $1.25 \mathrm{~km}$. A complete set of the SeaSoar maps and vertical sections can be found in Barth et al. (2000a).

Horizontal water velocity was measured using a 150$\mathrm{kHz}$ narrowband RDI shipboard acoustic Doppler current profiler and is reported in Ullman et al. (2000). The ensemble averaging interval was $150 \mathrm{~s}$ and the pulse and bin lengths were both set to $8 \mathrm{~m}$. Absolute velocity 


\section{SST $\left({ }^{\circ} \mathrm{C}\right), 0829$ UTC 20 June 1999}

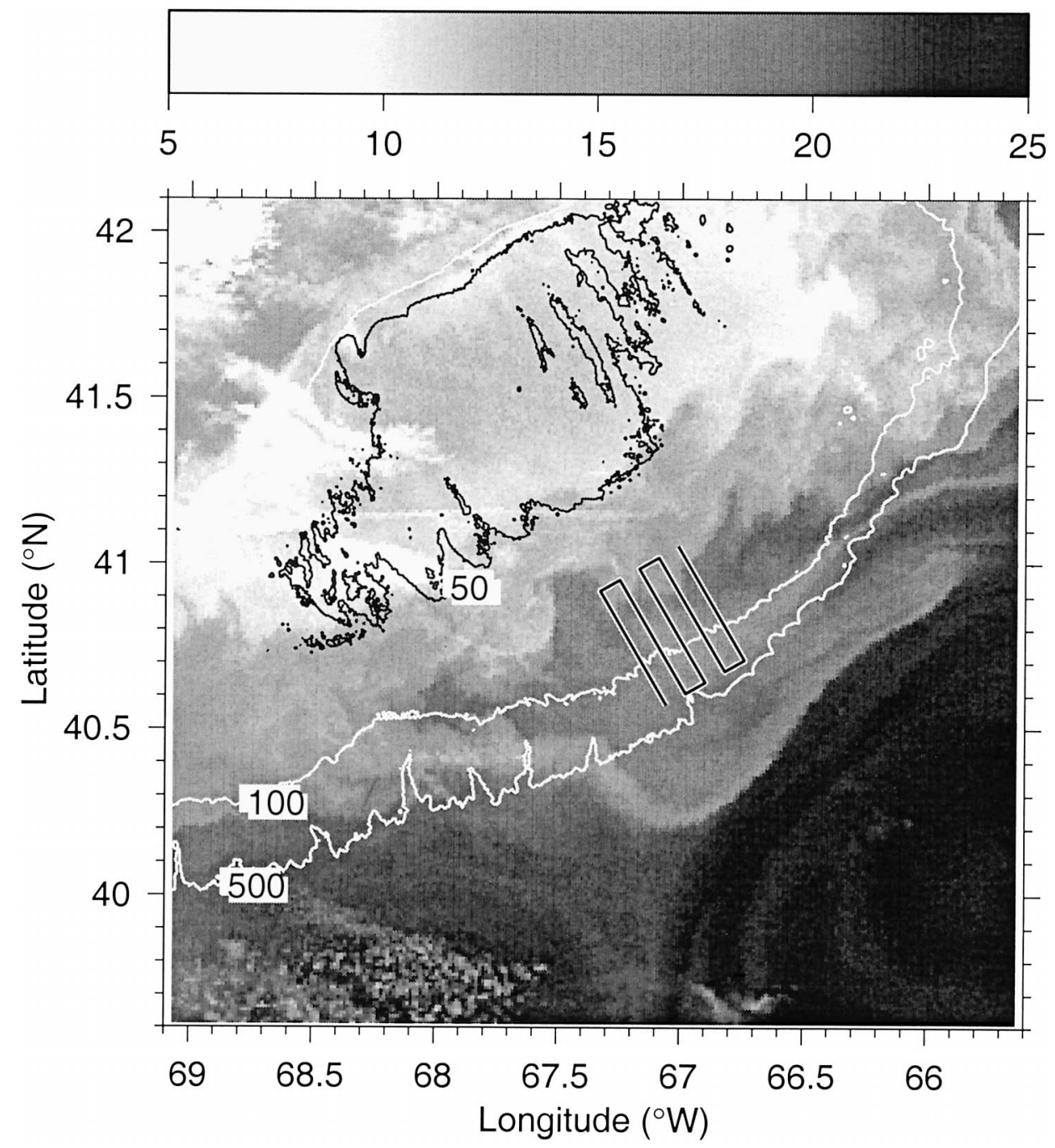

FIG. 1. Satellite sea surface temperature $\left({ }^{\circ} \mathrm{C}\right)$ on 20 Jun 1999. The SeaSoar sampling grid is shown as thick black lines; isobaths are in meters.

was calculated using ship's velocity derived from bottom tracking when available or from GPS P-Code navigation data. An Ashtech 3DF attitudinal GPS system was used to correct for gyrocompass variations.

SeaSoar was towed across the southern flank of Georges Bank in several basic patterns. The first was a "radiator" pattern consisting of 45-km-long legs oriented roughly perpendicular to the local isobaths (Fig. 1). Cross-bank lines were separated by $7.5 \mathrm{~km}$ for a total along-bank coverage of $30 \mathrm{~km}$. Each cross-bank line took approximately $3.4 \mathrm{~h}$ to complete depending on the phase of the tide. This pattern was centered near the 95-m isobath and sampled the shelfbreak front. After defining the local hydrography, bio-optical, and velocity fields around the shelfbreak front, a subsurface isopyc- nal float and a 15-m drogued drifter (see section 2c) were released. The subsurface float was tracked acoustically while towing SeaSoar on a butterfly pattern extending 20-30 km across the bank and $10 \mathrm{~km}$ alongbank. The pattern was repeated in place or shifted to the west depending on the location of the float. The butterfly pattern took approximately $6.5-8 \mathrm{~h}$ to complete depending on what phase of the tide it was started on and was repeated seven times before recovering the drifter and float.

\section{b. Advection with mean and tidal flow}

To create synoptic maps, the 2 -dbar, $1.25-\mathrm{km}$ averaged vertical profiles from a SeaSoar "radiator" pattern 
were advected to a common time using a time-independent, horizontally and vertically dependent mean flow and a time- and horizontally varying, depth-independent tidal velocity field. The mean velocity field was obtained by referencing each cross-bank section to the location of the shelf break, here defined as the 130$\mathrm{m}$ isobath, and then averaging the sections together. The tidal model consisted of a least squares fit of the steady plus two semidiurnal $\left(M_{2}\right.$ and $\left.S_{2}\right)$ and two diurnal $\left(K_{1}\right.$ and $O_{1}$ ) tidal constituents to the vertically averaged shipboard ADCP velocities collected during the 16 days the ship was on site and from a 15-day cruise on the R/V Endeavor (16-30 June 1999) in the same region. In addition, moored velocity data from an array in the middle of the study region (R. Schlitz 2002, personal communication) were also used in the analysis. The spatial fit, following Candela et al. (1992), used a second-order polynomial for the steady velocity and first-order polynomials (i.e., planes) for the four tidal constituents. The model fit is very similar to an analysis using all available shipboard ADCP data from southern flank Georges Bank Global Ocean Ecosystem Dynamics (GLOBEC) cruises (C. Flagg 2002, also see online at http:// www.oasdpo.bnl.gov/mosaic/globec), but we choose to use our fit because it better represents the tidal velocities in the smaller geographic area of interest here. When individual SeaSoar cross-bank vertical sections are compared with subsurface float positions, the 2-dbar, 1.25$\mathrm{km}$ averaged profiles making up that section are all advected to the time of the float fix using the tidal fit. Using a root-mean-square difference between the observed depth-averaged velocity and the tidal fit over the period of the first float deployment of $0.05 \mathrm{~m} \mathrm{~s}^{-1}$, and the maximum time interval between the closest SeaSoar profile and the float of $1000 \mathrm{~s}$, we estimate that the error in repositioning the SeaSoar profiles is less than about $50 \mathrm{~m}$. This is far less than the error in positioning the float acoustically (see next section).

\section{c. Subsurface float and surface drifter}

A satellite-tracked surface drifter and an acoustically tracked subsurface float were used to track fluid parcel trajectories in the vicinity of the shelfbreak front on the southern flank of Georges Bank. The surface drifter (Brightwaters Instrument Corporation Model 115) had a 10-m-long drogue centered at a depth of $15 \mathrm{~m}$. This drifter obtains its GPS location every $30 \mathrm{~min}$ and transmits the last seven positions via Argos every 90 s. On the ship, a GONIO Argos receiver was used to intercept the Argos messages when the drifter was within range and a computer attached to the receiver displayed the drifter positions. Argos messages from the drifter were also transmitted to the ship via twice-daily e-mail transfers. The surface drifter was equipped with a nighttime flasher to aid their recovery. Self-contained ONSET temperature loggers were placed at nominal depths of $0,5,10,13.3,16.7$, and $20 \mathrm{~m}$ on the drifter. The loggers recorded temperature every $30 \mathrm{~s}$ with a resolution of approximately $0.15^{\circ} \mathrm{C}$. The time constant of the logger is approximately $1 \mathrm{~min}$.

The subsurface float, the Coastal Ocean Lagrangian (COOL) float (Prater et al. 2003, unpublished manuscript, hereinafter PHRF) was developed to measure diapycnal velocities (a measure of diapycnal mixing) in the coastal ocean. The COOL float incorporates the features of the $f / h$ float (Rossby et al. 1994) and an isobaric vertical current meter (Voorhis 1968) that has been referred to as the VCM. Glass was used for the isopycnal float since it has a very small thermal expansion coefficient. Thus, the float will remain on the same density surface even if the temperature and salinity of the water changes but its density does not. If a water parcel is displaced vertically, it will either expand or contract because of the change in pressure and not change its potential density. Since the glass float is less compressible than seawater, it will not follow this water parcel. Therefore, a compressee is added to the float to make the float's compressibility be that of seawater.

The VCMs are isobaric floats equipped with vanes. Water flowing past these vanes rotates the float and, based on this rotation rate, the vertical velocity of the water can be calculated. Due to the isobaric nature of these floats, they mainly measure the vertical velocity of internal waves. The COOL float, however, being isopycnal, will move up and down with the internal waves. An example of this behavior will be shown later and is detailed in PHRF. The COOL float's pressure case is $2.2 \mathrm{~m}$ long and $0.095 \mathrm{~m}$ in diameter. Midway along its axis, eight vanes extending $0.34 \mathrm{~m}$ from the float's axis are oriented $15^{\circ}$ from the horizontal. The rotation of the float is measured with a Precision Navigation Vector $2 \times$ compass. A vertical velocity measured from such an isopycnal platform (i.e., by rotation of the float) is a diapycnal velocity. For further discussion of diapycnal velocity, see McDougall (1984). Note that a diapycnal velocity is used to effect diapycnal mixing in isopycnal-coordinate circulation models (Bleck et al. 1992).

The COOL float samples temperature and pressure every $64 \mathrm{~s}$. There was no conductivity sensor on this version of the COOL float. Since the equation of state for the float is known, as is its temperature and pressure, the salinity of the water the float is embedded in can be determined (Boebel et al. 1995). During the initial sinking phase of the float, the compass heading is recorded every $8 \mathrm{~s}$; after this period, it is recorded every $64 \mathrm{~s}$. The small onboard memory of the present float limited missions to less than 2.5 days with these sampling rates. At the end of the mission, the float released its drop weight, the compressee, and surfaced. The float was recovered and the data downloaded.

Tests of a prototype (Rajamony et al. 1996) and several short deployments of the COOL float (Hebert et al. 1997) showed that the rotation rate of the float was linearly proportional to the vertical velocity past the 


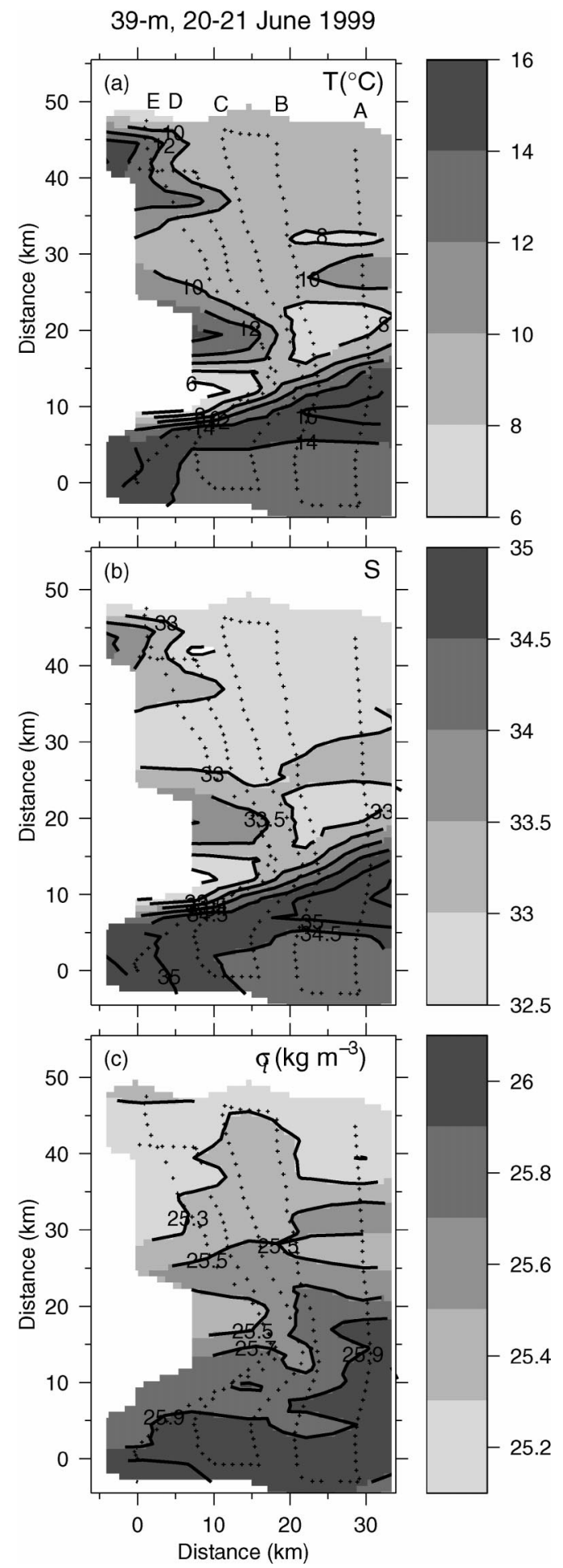

FIG. 2. Maps at 39-m depth of (a) temperature $\left({ }^{\circ} \mathrm{C}\right)$, (b) salinity, and (c) density $\left(\mathrm{kg} \mathrm{m}^{-3}\right)$ measured from SeaSoar on 20-21 Jun 1999. The fields have been rotated $30^{\circ}$ clockwise and measurements along lines A-E have been advected with the tidal and mean velocities to the time of the first observation at the northern end of line A. float. The vanes of the float appear to act like the threads of a screw; the lower the pitch, the more rotation of the float for the same vertical velocity. Since there are no moving parts, there is almost no lower velocity limit that the float can measure. However, with a compass accuracy of $2^{\circ}$, samples collected every $64 \mathrm{~s}$ limited the accuracy of vertical velocities to approximately 0.07 $\mathrm{mm} \mathrm{s}^{-1}$. In determining the vertical velocity and water displacement, the absolute rotation of the float must be determined. For most of the time series, the change in compass heading between adjacent samples was less than $90^{\circ}$. On occasion, the change was greater than $120^{\circ}$. For those cases, the adjacent headings were used to determine which way to rotate the float. In general, it was chosen to rotate the float in the direction of smallest rotation. Therefore, it is possible that the vertical velocity is underestimated (a $180^{\circ}$ change in $64 \mathrm{~s}$ gives a vertical velocity of $6 \mathrm{~mm} \mathrm{~s}^{-1}$ ) at that time and in the opposite direction.

The COOL float has a $12-\mathrm{kHz}$ pinger that is triggered precisely every $8 \mathrm{~s}$. This allow us to track the float through triangulation from the ship. The acoustic signal was received by the ship's hydrophone and displayed on a line scan recorder (LSR). A second precision sound source located on the ship was also recorded by the LSR. The range of the float from the ship was determined by the time interval between the two sources and assuming a sound speed of $1500 \mathrm{~m} \mathrm{~s}^{-1}$. The position of the float was determined at each closest approach of the float by the ship. The position of the ship and the range to the float at this time and several minutes before and after were used to determine the float's position. There is ambiguity in the possible float position from this calculation. However, with multiple passes in several hours, it is possible to choose the right position. The error in horizontal float positioning is estimated as $200 \mathrm{~m}$. Internal waves contribute "noise" of about $5 \mathrm{~m}$ in the vertical, the measured peak-to-peak wave amplitude, to an instantaneous float fix. For plotting float trajectories, the raw subsurface float fluxes are fit using a model consisting of a slowly varying current and a time-varying $M_{2}$ tidal flow, both of which are spatially independent.

\section{Results}

\section{a. Mean field and internal tide solibores}

During the 17-day cruise to the southern flank of Georges Bank in June 1999 the winds were generally weak with speeds rarely exceeding $10 \mathrm{~m} \mathrm{~s}^{-1}$ and more typically $5 \mathrm{~m} \mathrm{~s}^{-1}$ or less (Hebert et al. 1999). A satellite sea surface temperature image from 20 June 1999 showed typical cold water over Georges Bank and warm water over and seaward of the continental slope (Fig. 1). A warm-core Gulf Stream ring was located to the southeast of the study region and was clearly interacting with water on the southern flank of Georges Bank as 


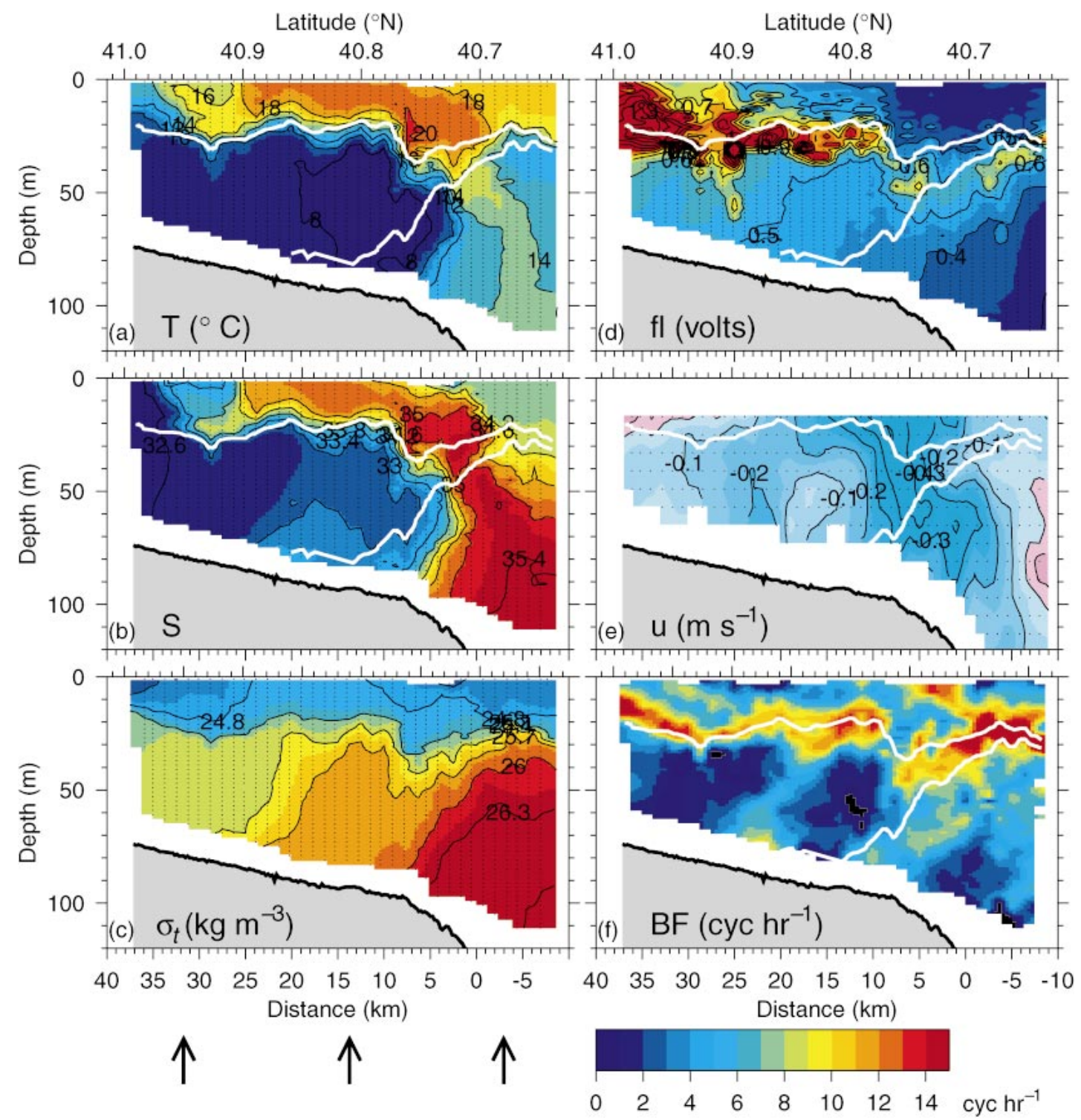

Fig. 3. A vertical section from the middle line (line C) of the shelfbreak front SeaSoar grid sampled from 0155 to 0510 UTC 21 Jun 1999: (a) temperature $\left({ }^{\circ} \mathrm{C}\right)$, (b) salinity, (c) density $\left(\mathrm{kg} \mathrm{m}^{-3}\right)$, (d) chlorophyll fluorescence (V), (e) along-bank velocity $\left(\mathrm{m} \mathrm{s}^{-1}\right)$ with positive values toward $60^{\circ}$ true, and (f) buoyancy frequency (cph). The thick white curves are the 25.2 and $25.8 \mathrm{~kg} \mathrm{~m}^{-3}$ density contours. The arrows beneath (c) indicate locations where density profiles were extracted for use in calculating internal wave propagation speeds.

evident by a streamer of cold, bank water being pulled off and around the anticyclonic warm-core ring. A series of three-dimensional mapping activities and Lagrangian drifter and float tracking experiments were carried out both at the location of the tidal mixing front, around the 60-m isobath, and at the shelfbreak front centered around the $90-100-\mathrm{m}$ isobaths. In this paper, only results from the shelfbreak front will be reported.

Before releasing a subsurface float in the vicinity of the shelfbreak front, a 2-day "radiator" grid survey was conducted from 20 to 21 June during a period of low wind speed $\left(<5 \mathrm{~m} \mathrm{~s}^{-1}\right)$. As described previously, each 2 -dbar, $1.25-\mathrm{km}$, averaged vertical profile was advected to the start time of the grid using both the mean flow and modeled tidal velocity field. Because the mean velocity field consists of a $0.30 \mathrm{~m} \mathrm{~s}^{-1}$ surface intensified jet centered on the 100-m isobath (not shown), the advected measurement locations are compressed in the along-bank direction (Fig. 2). Line E was slightly delayed relative to line $\mathrm{D}$ because of a needed SeaSoar repair. The tide is relatively weak $\left(0.4 \mathrm{~m} \mathrm{~s}^{-1}\right.$ or less $)$ at this location during neap tides as compared with tidal velocities on the northern flank of Georges Bank, which distort SeaSoar grids more significantly (Dale et al. 2003).

The temperature, salinity, and density anomaly (here- 


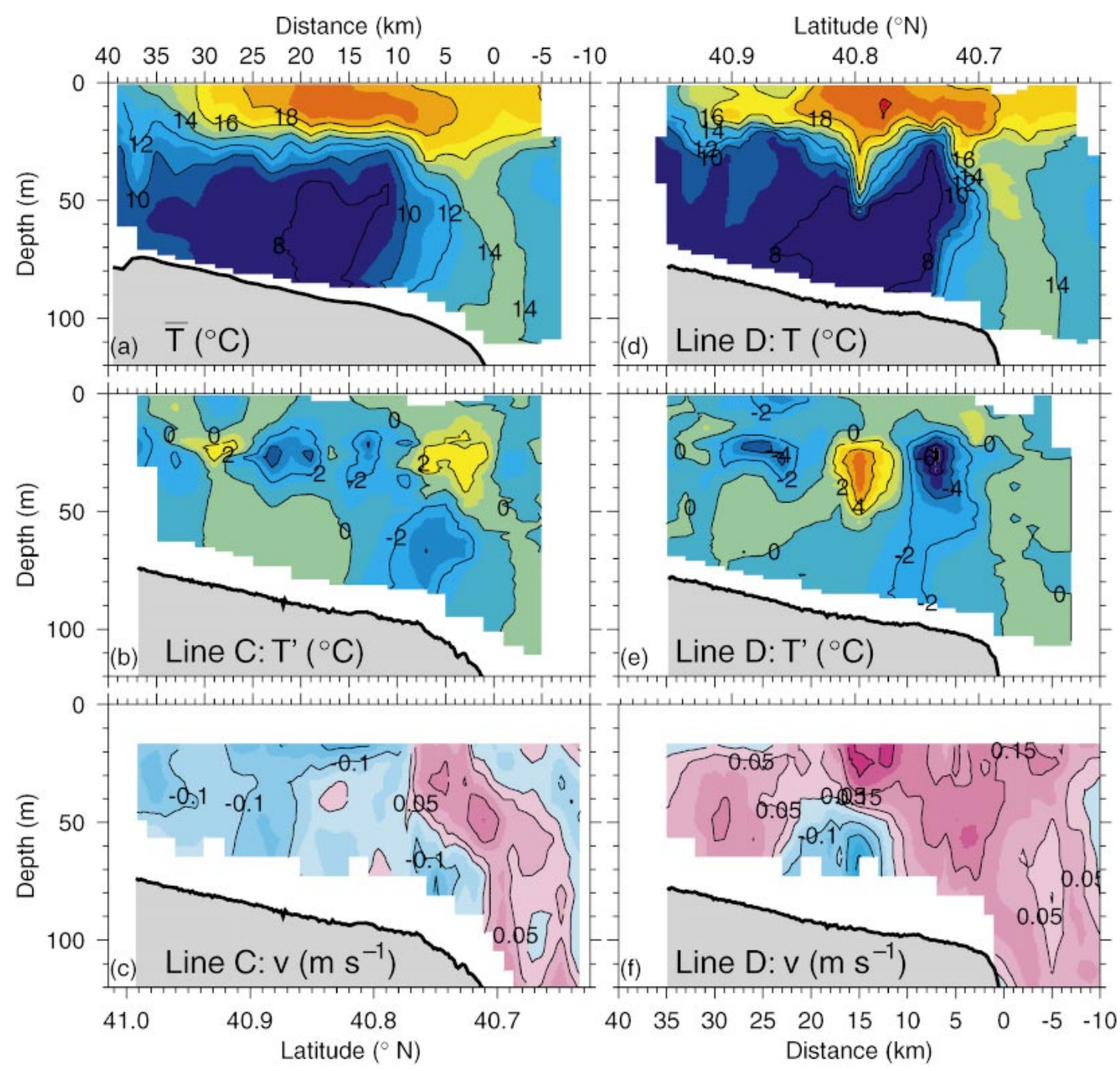

FIG. 4. Vertical sections sampled on 21 Jun 1999 from lines C (0155-0510 UTC; lower two left panels) and D (05500903 UTC; right panels) of the shelfbreak front SeaSoar grid: (a) mean temperature $\left({ }^{\circ} \mathrm{C}\right)$ from all five cross-bank sections, (b) temperature anomaly $\left({ }^{\circ} \mathrm{C}\right)$ from line $\mathrm{C}$, (c) cross-bank velocity $\left(\mathrm{m} \mathrm{s}^{-1}\right)$ with positive values toward $330^{\circ}$ true from line $\mathrm{C}$, (d) temperature $\left({ }^{\circ} \mathrm{C}\right)$ from line $\mathrm{D}$, (e) temperature anomaly $\left({ }^{\circ} \mathrm{C}\right)$ from line $\mathrm{D}$, and (f) cross-bank velocity $\left(\mathrm{m} \mathrm{s}^{-1}\right)$ from line D.

inafter, "density") fields at $39 \mathrm{~m}$ obtained from this synoptic map and rotated $30^{\circ}$ clockwise from an eastnorth coordinate system are shown in Fig. 2. The SeaSoar profile in the southwest corner is arbitrarily chosen as the origin of the rotated coordinate system. A shelfbreak density front separating cold, fresh bank water from warm, salty slope water runs from NE to SW crossing the local isobaths (a front following the isobaths would parallel the $x$ axis in this rotated coordinate system). The warm, salty, and light anomalies onbank from the shelfbreak front, the best example of which is located at $15 \mathrm{~km}$ in the $x$ direction and $20 \mathrm{~km}$ in the $y$ direction, are created by strong local depressions in the upper layer depth caused by onbank propagation of the internal tide (discussed in more detail below).

A typical cross-bank section from the center of the survey grid (line C) is shown in Fig. 3. A warm, salty layer in the upper $20 \mathrm{~m}$ is found over the center part of the cross-bank section consistent with the satellite temperature field (Fig. 1). The presence of relatively cool and fresh upper-layer water offshore of about the 120$\mathrm{m}$ isobath is due to mesoscale variability introduced by the presence of a warm-core ring to the southeast of the study region. At depth, the shelfbreak front separating cold, fresh shelf water from warm, salty slope water is readily apparent. The foot of the front, approximated by the $26.15 \mathrm{~kg} \mathrm{~m}^{-3}$ density contour, is between the 90 $\mathrm{m}$ and 100-m isobaths. The "cold pool" is located within $60 \mathrm{~m}$ of the bottom and onbank of the shelfbreak front. A plot of buoyancy frequency (Fig. 3f) shows a strong pycnocline at $20-25 \mathrm{~m}$ and the shelfbreak front. Along-bank velocity (Fig. 3e) shows a $0.4 \mathrm{~m} \mathrm{~s}^{-1}$ jet to 


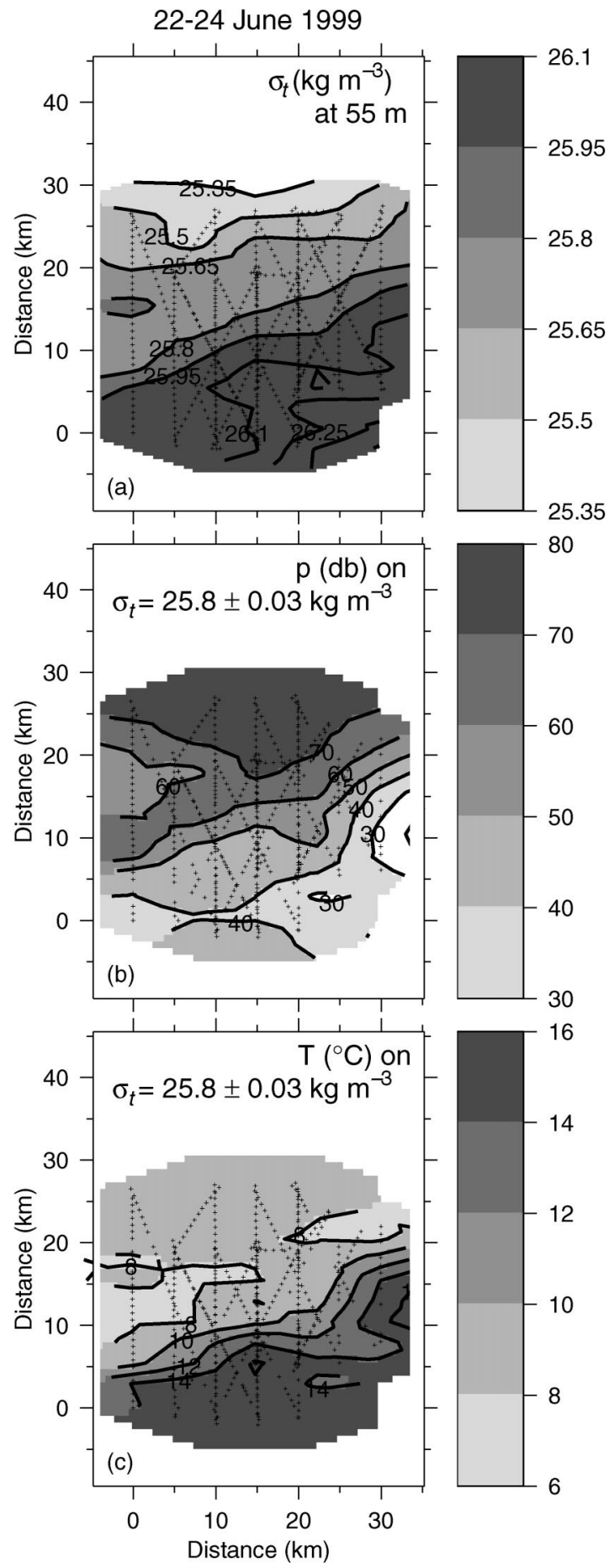

FIG. 5. (a) Density $\left(\mathrm{kg} \mathrm{m}^{-3}\right)$ at $55 \mathrm{~m}$ and (b) pressure (dbar) and (c) temperature $\left({ }^{\circ} \mathrm{C}\right)$ on $\sigma_{t}=25.8 \pm 0.03 \mathrm{~kg} \mathrm{~m}^{-3}$ from all the butterfly sampling conducted while tracking a subsurface COOL float from 0138 UTC 22 Jun to 0112 UTC 24 Jun 1999.

the southwest centered near the 100-m isobath (crossbank velocity is shown in Fig. 4c). High chlorophyll fluorescence (Fig. 3d) is found following and just beneath the shallow pycnocline.
The hydrographic and bio-optical fields show a rapid deepening of the base of the surface layer from 25 to $40 \mathrm{~m}$ near $40.77^{\circ} \mathrm{N}$, with a gradual return to the more typical $25-\mathrm{m}$ depth over about $15 \mathrm{~km}$ in the offbank direction (best seen in density, Fig. 3c). This is the manifestation of an internal tide "solibore" (Henyey and Hoering 1997) propagating onbank from its formation region near the shelf break (Lamb 1994). Henyey and Hoering (1997) define a solibore using Baines' (1986) description: "the larger-amplitude wave trains which are of tidal origin and are generated at the shelf break or other topographic features such as ridges and banks." Henyey and Hoering (1997) go on to say that a solibore will begin life more borelike, but as the energy supply is reduced it will end up more wavelike. We see evidence for both borelike structures and packets of individual waves.

An even stronger signal of the internal tide solibore is evident in the line D SeaSoar/ADCP cross-bank section (Fig. 4, right panels). The thermocline is depressed over $30 \mathrm{~m}$ near $40.80^{\circ} \mathrm{N}$ and the leading edge-the solibore is propagating to the northwest (to the left in Figs. 3 and 4)-is steeper than the trailing edge. The temperature anomaly is formed by subtracting the mean temperature section over the five cross-bank sections (Fig. 4a). On line $\mathrm{C}$ (Fig. 4, left panels) there is $2^{\circ} \mathrm{C}$ warm anomaly at 20-30-m depth near $5 \mathrm{~km}$ from the shelf break. The solibore is more evident on line D (Fig. 4 , right panels) with a $5^{\circ} \mathrm{C}$ warm anomaly at $30-40-\mathrm{m}$ depth near $40.80^{\circ} \mathrm{N}$ and a cold anomaly of up to $6^{\circ} \mathrm{C}$ near $40.74^{\circ} \mathrm{N}$ (Fig. 4e). The cold anomaly, or elevation of the thermocline trailing the solibore, is due to onbank tidal flow encountering the bank edge. The rapid depression followed by a slow elevation trailing the internal solibore is captured in the numerical modeling experiments of Lamb (1994). Cross-bank velocity fields show a mode one vertical structure, onbank flow above the pycnocline and offbank flow beneath, associated with the internal tide solibore on lines C and D (Figs. $4 \mathrm{c}, \mathrm{f})$.

The $1.25-\mathrm{km}$ spatially averaged SeaSoar data do not show individual waves within the internal solibore depression. A set of rank-ordered nonlinear internal waves is often observed within the internal tidal bore packet (e.g., Apel et al. 1975; Liu 1988). In contrast, individual waves do not appear in the solibore depression as it propagates up to $35 \mathrm{~km}$ onbank from the shelfbreak in the numerical solutions of Lamb (1994). Although the horizontal resolution of the SeaSoar measurements$300 \mathrm{~m}$ at middepth for the unaveraged profiles-may not be sufficient to resolve individual waves, we speculate that there may not be individual waves in the depression because these observations are near the generation site of the solibores. That is, rank-ordered individual waves within the packet would be expected farther away from the generation site as nonlinearity and dispersion allow the shelfbreak depression to 


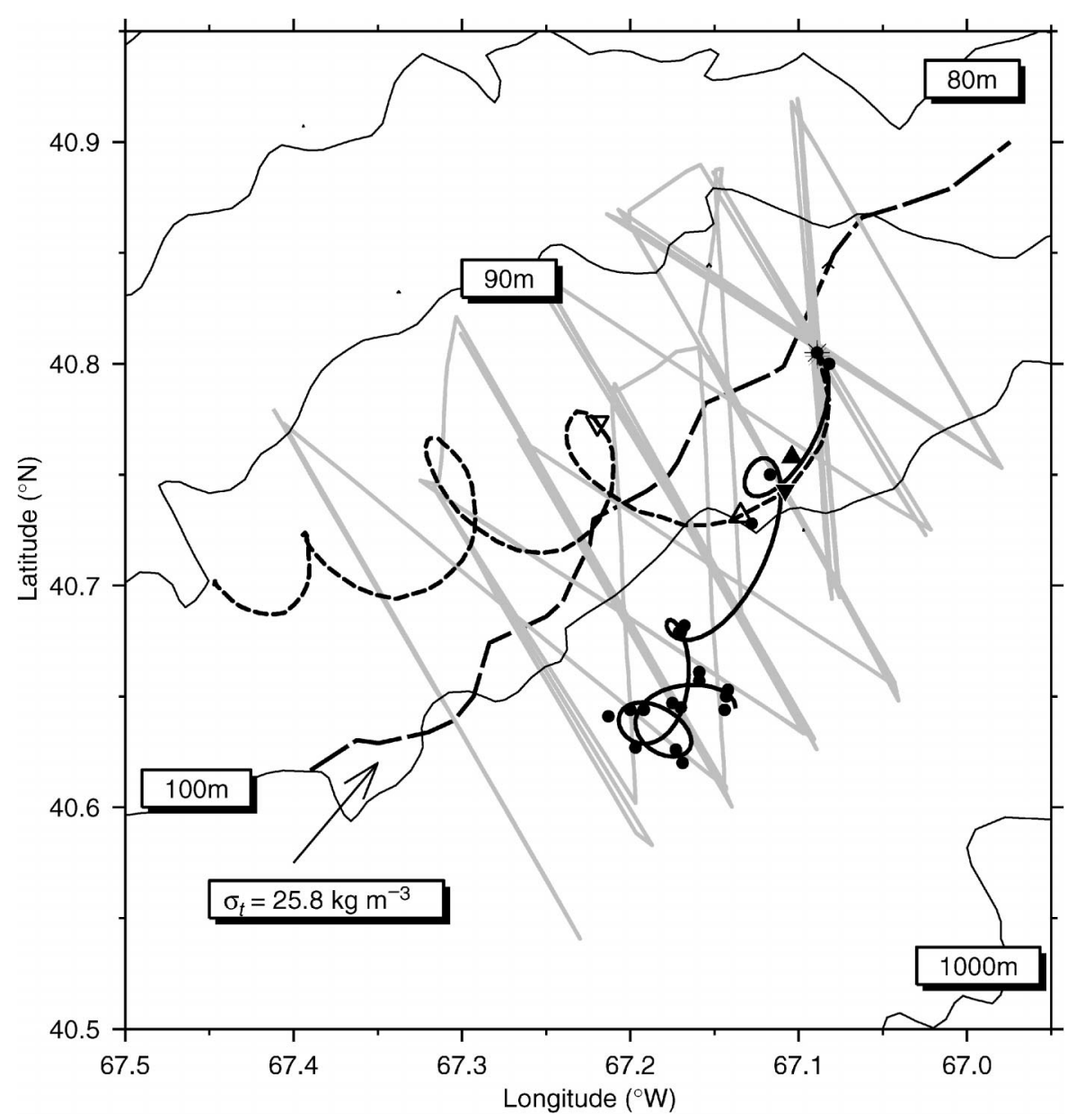

FIG. 6. Trajectories of a subsurface COOL float (thick solid curve) and a surface drifter (thick, short-dashed curve) from 22-24 Jun 1999. The continuous float trajectory is from a model fit (see text) to the observed float locations (filled symbols). The orientation of the shelfbreak front $(25.8 \mathrm{~kg}$ $\mathrm{m}^{-3}$ at $55 \mathrm{~m}$ ) is indicated by a thick, long-dashed curve. SeaSoar sampling and acoustic tracking were done along the butterfly patterns (gray curves), which were shifted westward as the float and drifter were advected with the mean flow. Triangles indicate float (filled) and drifter (open) positions at 173.199 31; upside-down triangles indicate float (filled) and drifter (open) positions at 173.55208 Isobaths are in meters.

evolve. A set of internal solitons within a packet was measured by SeaSoar during summer 1996 in $65 \mathrm{~m}$ of water over $50 \mathrm{~km}$ from the shelfbreak near $70.5^{\circ} \mathrm{W}$, to the west of the present study site but with a similar hydrographic and physical setting (J. Barth 2002, unpublished data). Their wavelength was estimated as 650 $\mathrm{m}$ - the distance between SeaSoar profiles in water 65 $\mathrm{m}$ deep is $150 \mathrm{~m}$-in the range of wavelengths estimated using measurements from a nearby mooring (Levine and Boyd 1998). Given these wavelengths, the present SeaSoar measurements could have marginally resolved individual waves, but we suspect that they are absent because of the proximity to the generation point for the internal solibores.

The internal solibore is also apparent in the 39-mdepth property fields (Fig. 2), although the sharp horizontal fronts are smoothed somewhat by the contouring algorithm. Low-density water at $39 \mathrm{~m}$ brought down by the propagating internal tide solibore can be seen at different cross-bank locations on successive sections. Specifically, low density at $y=5 \mathrm{~km}$ on line B, at $y=$ $12.5 \mathrm{~km}$ on line $\mathrm{C}$ and at $y=20 \mathrm{~km}$ on line $\mathrm{D}$ are manifestations of the same internal tide solibore propagating onbank. Low-density water at $y=32 \mathrm{~km}$ on line $\mathrm{A}$ is from a solibore formed during the previous tidal cycle to the one that formed the solibore observed on lines B-D.

The propagation speed of the internal tide solibore is estimated as $0.30-0.45 \mathrm{~m} \mathrm{~s}^{-1}$ by comparing the time and location of the feature on successive sections and accounting for the presence of a cross-bank barotropic tidal flow. Note that because of the presence of the along-bank mean flow, the sections near the middle of the map are nearly collocated when advected to a com- 

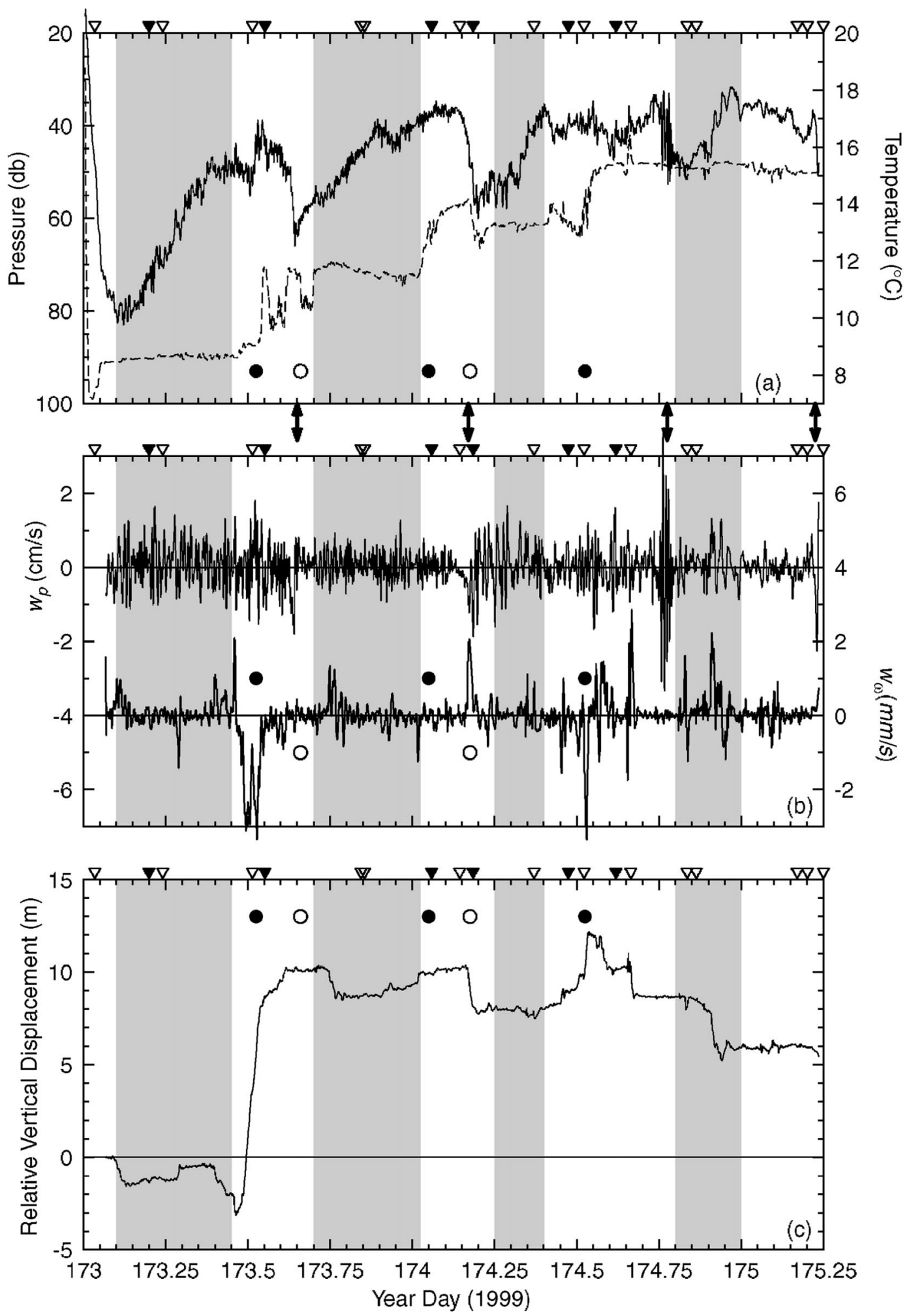

FIG. 7. (a) Pressure (solid curve) and temperature (dashed curve) recorded by the float from 0008 UTC 22 Jun to 0657 UTC 24 Jun 1999. Upside-down triangles show the times of float position fixes with the filled upside-down triangles indicating the times of float positions plotted together with SeaSoar vertical sections in Figs. 8 and 9. Double-ended arrows indicate start times of solibore passage. Gray vertical bars indicate times of isothermal rise. (b) Vertical velocity $\left(w_{p}\right)$ of the isopycnal float based on the measured pressure (top curve) and diapycnal velocity (water flowing past the float) from the rotation rate of the float. The data have been smoothed with a 5-point (256 s) moving average. (c) Vertical displacement of the float (or isopycnal) relative to a water parcel (e.g., the integral of $-w_{\omega}$ ). Filled (open) circles indicate warming (cooling) events. 

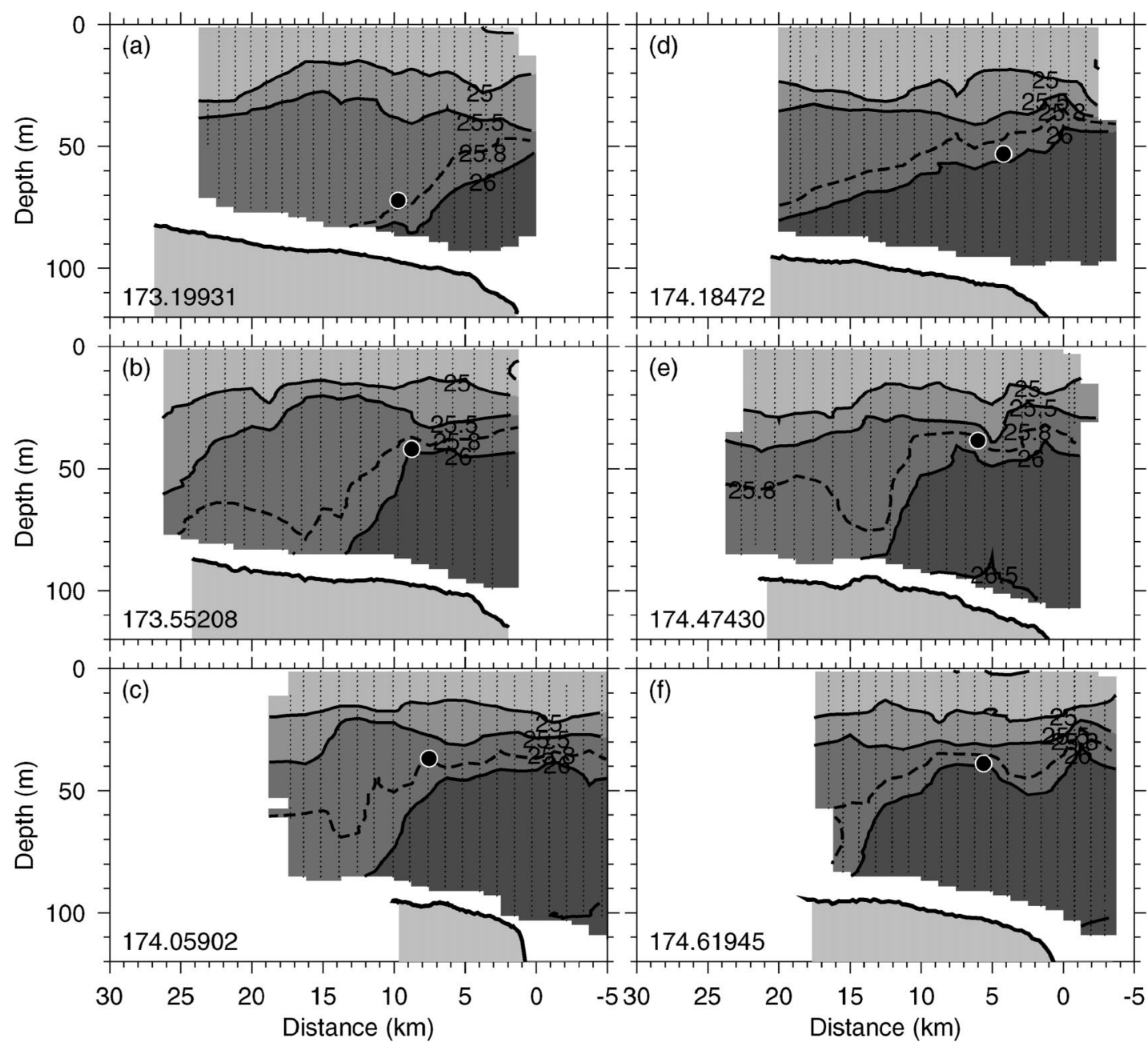

FIG. 8. Vertical sections of density $\left(\mathrm{kg} \mathrm{m}^{-3}\right)$ at selected subsurface float fix times. The float positions are indicated by black filled circles where the size of the circle roughly indicates the error in positioning. The $25.8 \mathrm{~kg} \mathrm{~m}^{-3} \mathrm{density}$ contour is dashed.

mon time. Therefore, estimates of the internal tide solibore speed are essentially from the same cross-bank section. The observed internal tide solibore phase speed can be compared with theoretical mode-1, semidiurnal internal wave propagation speeds estimated using density profiles from three locations across the southern flank of the bank (see locations indicated in Fig. 3). The estimated theoretical phase speeds are 0.40, 0.46, and $0.67 \mathrm{~m} \mathrm{~s}^{-1}$ at $40.95^{\circ}, 40.81^{\circ}$, and $40.68^{\circ} \mathrm{N}$, respectively. The phase speed is largest in the deep, highly stratified offbank region and slows as the shallow, more weakly stratified water column on the bank is approached. The observed propagation speed is closer to the slow theoretical phase speeds consistent with the fact that the features were observed onbank of the shelfbreak front. The solibore apparent in the repeated sections is formed near the shelf break and propagates onbank when the on-offbank tidal velocity becomes slack and begins to flow onbank (Lamb 1994; Loder et al. 1992; Dale et al.
2003). The influence of the internal solibore on the behavior of a subsurface float will be described below.

\section{b. First subsurface float deployment}

After the shelfbreak frontal region was mapped using SeaSoar and shipboard ADCP, a subsurface COOL float was released on the onbank side of the front. A target density of $25.8 \mathrm{~kg} \mathrm{~m}^{-3}$ was chosen and the float was released at 0008 UTC 22 June 1999 at $40.805^{\circ} \mathrm{N}$, $67.089^{\circ} \mathrm{W}$. Immediately thereafter a surface drifter equipped with temperature sensors on its subsurface drogue was released at the same location. A series of "butterfly" sampling patterns were then occupied using SeaSoar and shipboard ADCP. The butterfly patterns were designed to give a useful cross-bank representation of the hydrographic and velocity fields, to allow acoustic tracking of the subsurface float through triangulation and to be about 0.5-0.7 $M_{2}$ tidal cycles long (Fig. 5). 

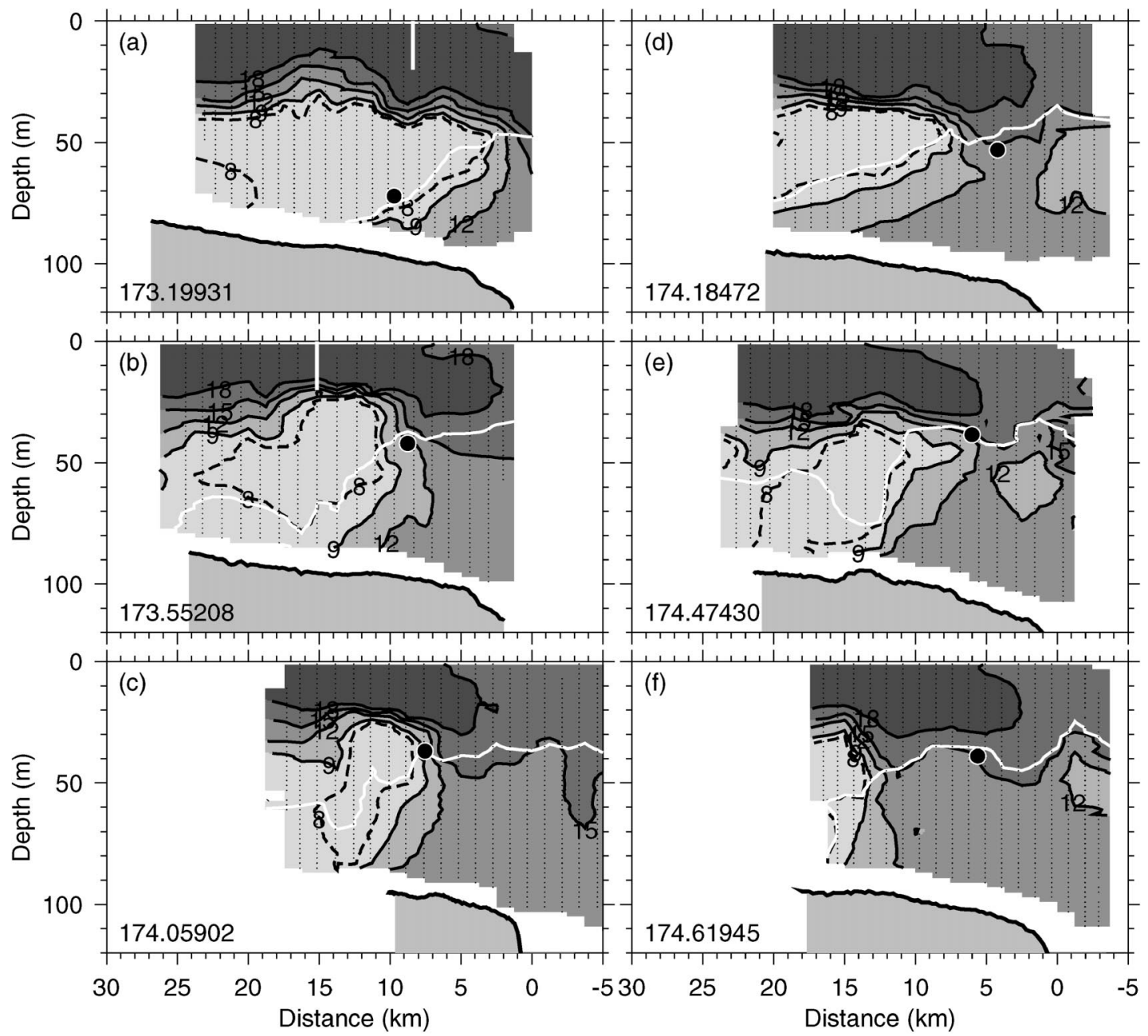

FIG. 9. Vertical sections of temperature $\left({ }^{\circ} \mathrm{C}\right)$ at selected subsurface float fix times. The float positions are indicated by black filled circles where the size of the circle roughly indicates the error in positioning. The $25.8 \mathrm{~kg} \mathrm{~m}^{-3} \mathrm{density} \mathrm{contour}$ is the white curve. Thick white vertical bars in (a) and (b) indicate position and depth extent of surface drifter and drogue.

The butterfly patterns were shifted westward as needed as the float moved with the mean flow. The density at $55 \mathrm{~m}$ from all the SeaSoar butterfly sampling (Fig. 5a) shows a fairly linear mean shelfbreak front, again running from NE to SW slightly crossing the isobaths. The many repeated crossings of the front that go into this map serve to average out the effects of tides and internal solibores. The $25.8 \mathrm{~kg} \mathrm{~m}^{-3}$ density surface rises from $70 \mathrm{~m}$ onbank of the shelfbreak front to about $25 \mathrm{~m}$ in the offbank direction (Fig. 5b). Last, a strong temperature gradient exists along the $25.8 \mathrm{~kg} \mathrm{~m}^{-3}$ density surface separating cold shelf water from warm slope water (Fig. 5c).

The surface drifter moved off to the west with the mean flow (average speed of $0.18 \mathrm{~m} \mathrm{~s}^{-1}$ ) modulated by the $M_{2}$ tidal flow (Fig. 6). In contrast, the subsurface float translated more slowly westward (mean speed of $0.09 \mathrm{~m} \mathrm{~s}^{-1}$ ) and moved about $15 \mathrm{~km}$ in the offbank (cross-front) direction. As will be demonstrated further, the subsurface float moved up the density surface (Fig. $5 b)$ as it transited in the offbank direction.

A time series of pressure and temperature reveals the behavior of the float during this 50-h mission (Fig. 7a). The float descended through the cold pool, sampling water less than $8^{\circ} \mathrm{C}$, before reaching its target density of $25.8 \mathrm{~kg} \mathrm{~m}^{-3}$ at a depth of $80 \mathrm{~m}$ (13 m above bottom) and a temperature of $8.5^{\circ} \mathrm{C}$.

As described in section $2 b$, cross-bank SeaSoar hydrographic sections from butterfly lines closest in time to a float fix were advected using a tidal velocity model to the time of the float fix (Figs. 8 and 9). Errors in float position are indicated by the size of the filled black circles and the $25.8 \mathrm{~kg} \mathrm{~m}^{-3}$ density contour is dashed. The first SeaSoar section after the float has reached its target density and has begun to rise is shown in Figs. $8 \mathrm{a}$ and $9 \mathrm{a}$. The series of sections shows how the float moved up the frontal isopycnals from a region of cold to warm water. 


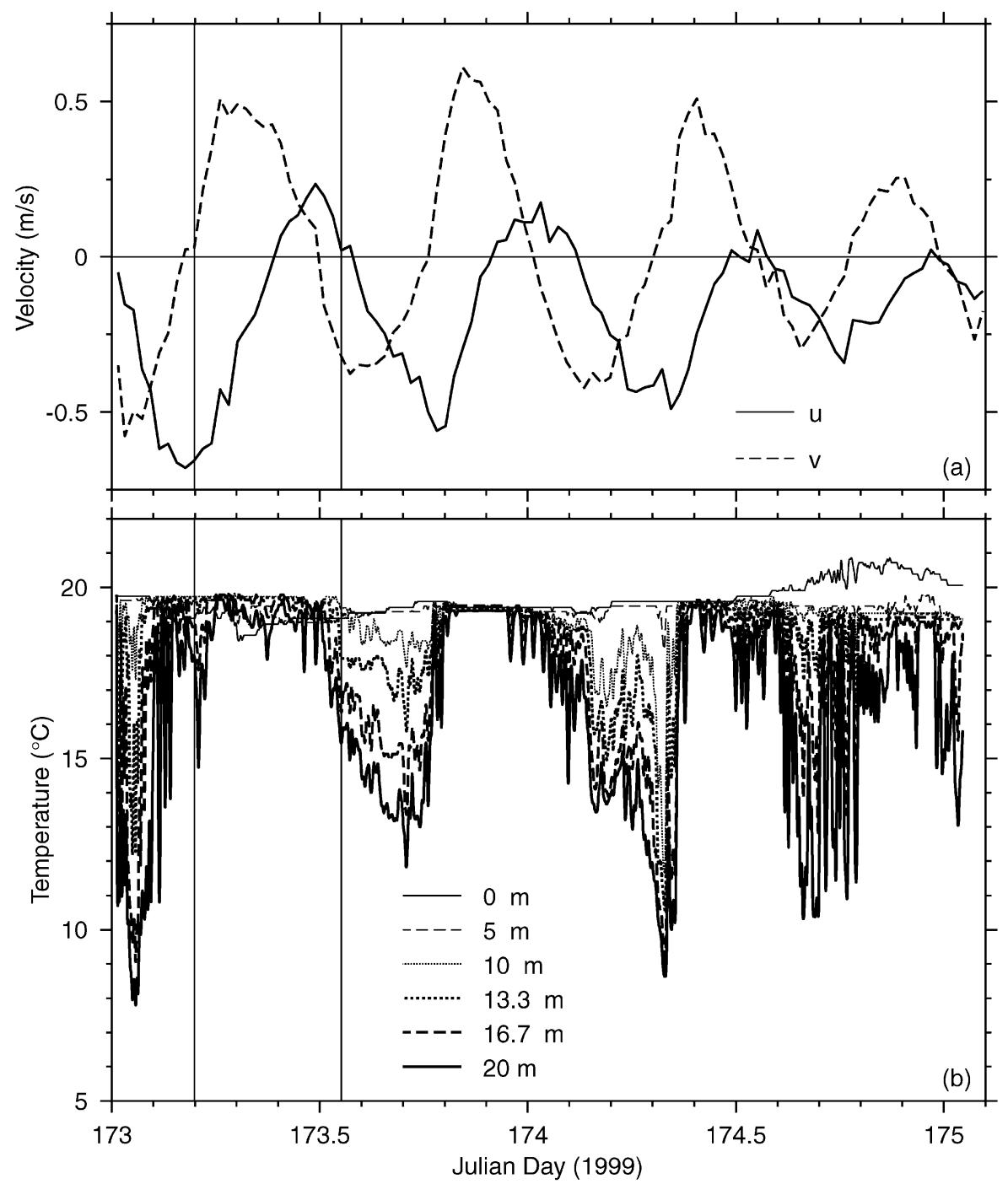

FIG. 10. (a) Along-bank $(u)$ and onbank $(v)$ velocity of the surface drifter obtained by first-differencing the GPS positions. (b) Temperature recorded by the loggers at different depths on the surface drifter's drogue. Vertical lines indicate times of float fixes and advected SeaSoar sections (see Figs. $9 \mathrm{a}, \mathrm{b})$.

To determine the degree to which the float was isopycnal and its actual density, the SeaSoar observation closest to the float's location both in depth and in horizontal location can be examined. Details of this comparison can be found in PHRF. The mean density over 14 observations (with a temperature and pressure range of $9^{\circ} \mathrm{C}$ and $35 \mathrm{dbar}$ ) is $25.84 \mathrm{~kg} \mathrm{~m}^{-3}$ with a standard deviation of $0.10 \mathrm{~kg} \mathrm{~m}^{-3}$, confirming the float's target density and that it was isopycnal given the error in positioning the float and in interpolating the SeaSoar observations.

The float record (Fig. 7) contains evidence for the mean vertical velocity over the float's mission, internal solibores, isothermal rebound of the density surfaces after the passage of the internal tide, along-isopycnal diffusion, and diapycnal mixing. We describe each of these in detail in the following sections.

\section{1) Mean vertical velocity}

Because of the large vertical excursions of isopycnals by the solibores and the internal tide, to calculate the mean vertical velocity over the entire float record we use three cycles between the deepest excursions recorded by the float. On average, the float moved from $80 \mathrm{~m}$ at day 173.125 to $50 \mathrm{~m}$ at day 174.835 , for an average vertical velocity of $2.0 \times 10^{-4} \mathrm{~m} \mathrm{~s}^{-1}$ or 17.5 $\mathrm{m}$ day $^{-1}$. Vertical velocities during the three semidiurnal cycles between 173.185 and 174.835 are 31.0, 9.5, and 

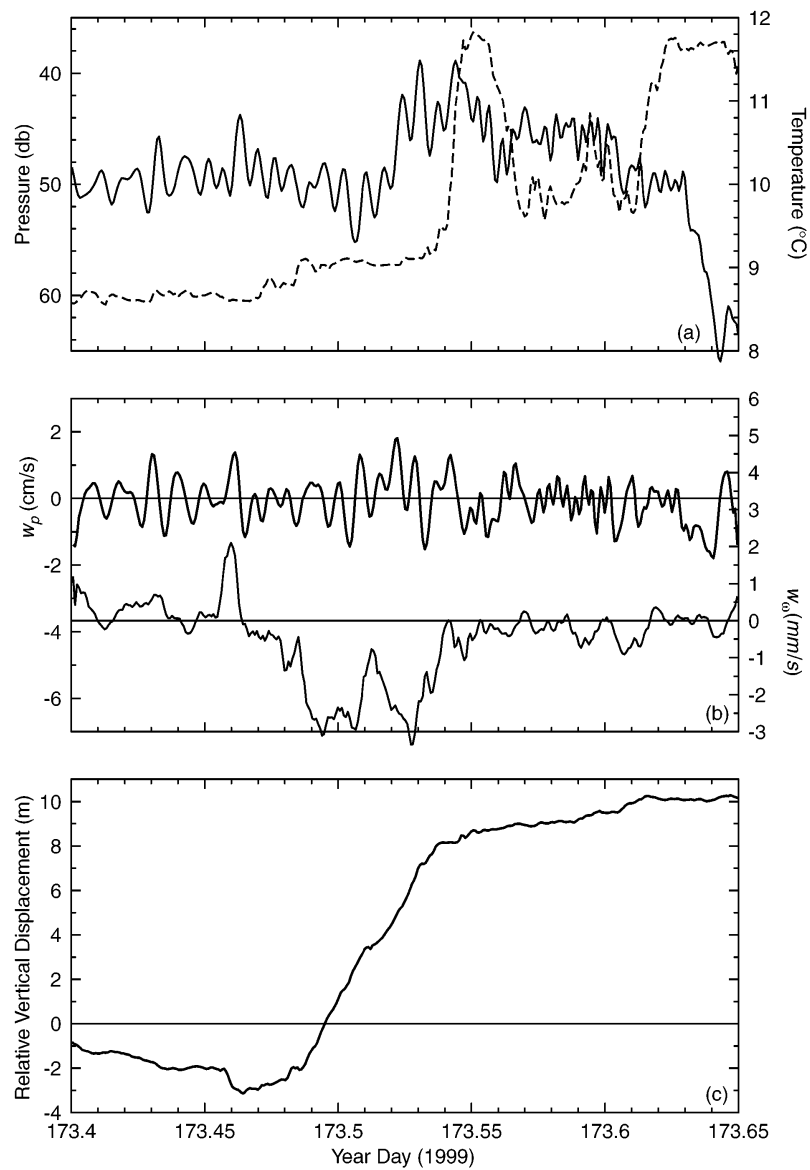

FIG. 11. As in Fig. 7 but for 0936-1536 UTC 22 Jun.

$12.0 \mathrm{~m} \mathrm{day}^{-1}$, consistent with the front being the steepest near the foot of the shelfbreak front.

\section{2) INTERNAL SOLIBORES}

The float measures the passage of at least three, and perhaps four, internal tidal solibores (double-ended arrows in Fig. 7) each of which has a different character regarding the presence or absence of individual waves associated with the internal solibore front. Evidence that the float does indeed track water parcels even as they move vertically is found near day 174.75 during the passage of an internal solibore. A closer look at this event can be found in PHRF. The float underwent a series of large undulations in pressure (up to $20 \mathrm{~m}$ peakto-peak) with vertical velocities of $\pm 0.03 \mathrm{~m} \mathrm{~s}^{-1}$. Throughout this time the temperature stayed nearly isothermal and, more important, the flow of water past the float, indicated by $w_{\omega}$ in Fig. 7b, was small. The float is moving with the water. Using a propagation speed of $0.30(0.45) \mathrm{m} \mathrm{s}^{-1}$, the estimated wavelength between individual waves in this packet is $190(280) \mathrm{m}$, far too short to be resolved by the SeaSoar sampling.

Earlier in the record, the float measures the passage of an internal tide solibore (near day 173.65) where the

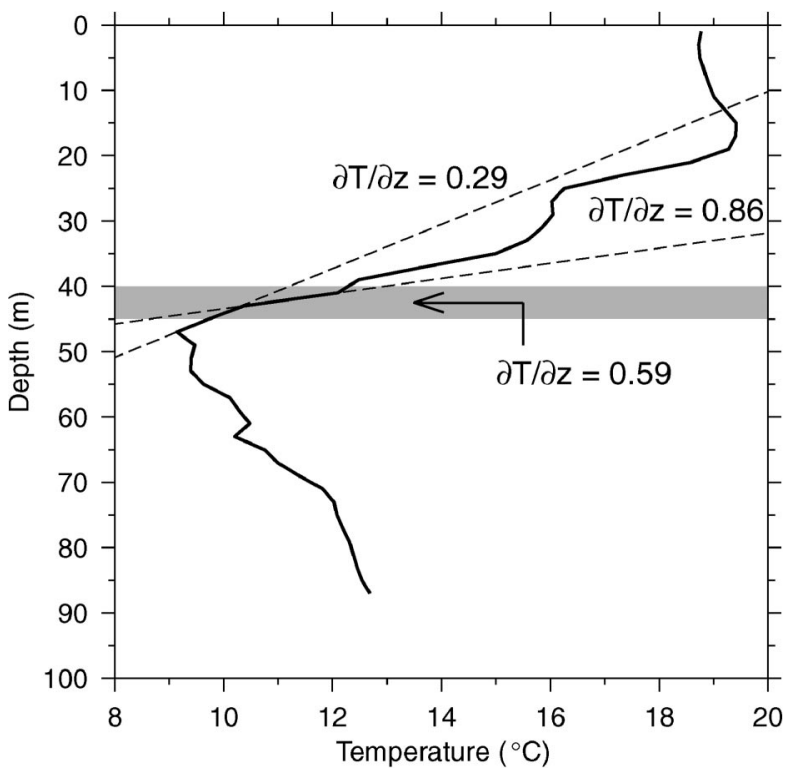

FIG. 12. Temperature profile at $8.3 \mathrm{~km}$ onbank from the SeaSoar section advected to the float fix time 173.55208 (see Fig. 9b). A vertical temperature gradient of $0.59^{\circ} \mathrm{C} \mathrm{m}^{-1}$ is estimated in the depth range $40-45 \mathrm{~m}$ as indicated by the gray bar. Dashed lines show vertical temperature gradients of $0.86^{\circ} \mathrm{C} \mathrm{m}^{-1}$ and $0.29^{\circ} \mathrm{C} \mathrm{m}^{-1}$ at 42 and $46 \mathrm{~m}$, respectively.

pressure increases rapidly by about $20 \mathrm{~m}$. During descent the float records a negative vertical velocity $w_{p}$ (Fig. 7b) of up to $-0.015 \mathrm{~m} \mathrm{~s}^{-1}$ and the temperature remains isothermal. This is the adiabatic depression of the isopycnal surfaces during the passage of the internal tide solibore. In this solibore the float does not measure any distinguishable individual waves, consistent with the SeaSoar results presented in Figs. 3 and 4. We speculate that these differences could be due to differences in the vertical stratification and nontidal velocity near the shelfbreak during solibore formation. Immediately following the passage of the solibore front, near day 173.66, the float cools. However, the float does not record a significant positive diapycnal velocity at this time, and so this cooling could only come from alongisopycnal diffusion.

At day 174.17 another solibore front passes at 12.42 $\mathrm{h}$ or 0.5175 days after the previous one at day 173.65 . The float again records a negative vertical velocity $w_{p}$ of about $-0.015 \mathrm{~m} \mathrm{~s}^{-1}$. Immediately after the passage of the solibore, near day 174.175, the float again cools and this time the float records a positive diapycnal velocity (flow up past the float) of up to $0.002 \mathrm{~m} \mathrm{~s}^{-1}$, perhaps indicative of turbulent mixing in the trail of the propagating solibore.

The float shows no signs of cooling in the wake of the solibore passage at 174.75 , most likely because the float has moved across the shelfbreak front and is now in a region of weaker vertical and horizontal temperature gradients (see Fig. 9f). Just before recovery, a final in- 


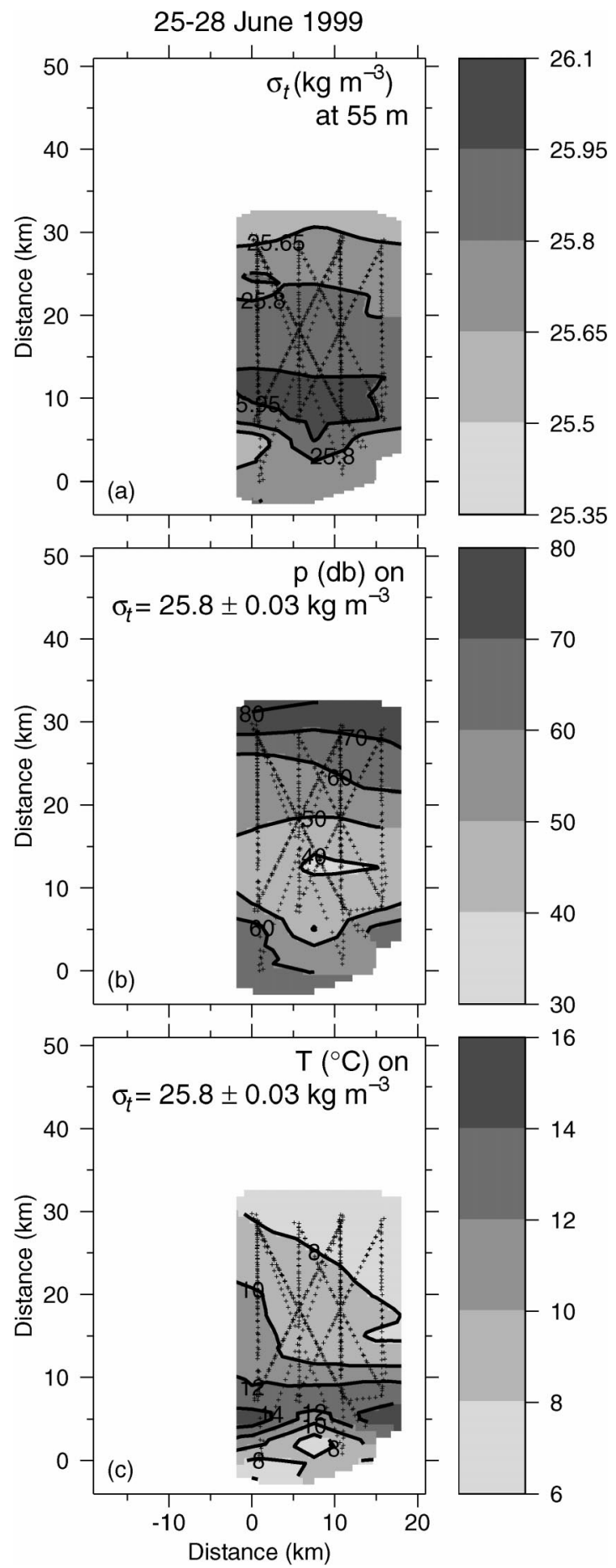

FIG. 13. As in Fig. 5 but from all the butterfly sampling conducted while tracking a subsurface COOL float from 2315 UTC 25 Jun to 0312 UTC 28 Jun 1999.

ternal solibore passes the subsurface float near day 175.25 .

The surface drifter that was released at the same time and location as the subsurface drifter exhibits significant along- and onbank semidiurnal tidal velocities (Fig. 10a). Temperature records from thermistors located between the surface and $20 \mathrm{~m}$ also show semidiurnal periodicity (Fig. 10b). The drogued drifter records periods when the upper $20 \mathrm{~m}$ is relatively homogeneous separated by periods when stratification rebuilds in the upper layer. Since the drifter is moving with the water, the only way this signal could arise is from changes in the upper layer stratification. The asymmetric signal, that is, slow rebuilding of the stratification versus the sudden onset of isothermal conditions, can be explained by the propagation of the internal tide solibore past the surface drogue. This can be shown be examining the drogued drifter and subsurface float records, and the advected SeaSoar sections early in the deployment before the surface drifter advects too far away. At day 173.199 31, the drogued drifter is slightly offbank of the subsurface float (see Figs. 6 and 9a) and the drifter temperature records show relatively homogeneous temperatures (Fig. 10b). At this time the drogued drifter is offbank of the location of the internal tide solibore that has recently passed both the drifter and float (at 173.15) and the temperature loggers are all located in the approximately $19^{\circ} \mathrm{C}$ upper layer. By the time of the 173.55208 float fix, the drogued drifter is located in the trailing region of the internal tide solibore where the thermocline has elevated high enough that the 20-m temperature sensor is measuring water less than $16^{\circ} \mathrm{C}$ (Figs. 6 , $9 \mathrm{~b}$, and 10b). The solibore front at 173.55208 is at approximately $19 \mathrm{~km}$ onbank of the shelfbreak (Fig. 9b), consistent with propagation at $0.30 \mathrm{~m} \mathrm{~s}^{-1}$ from its location just onbank of the float at 173.199 31. Note that the sudden onset of isothermal conditions occurs shortly after the barotropic tide has reversed from off- to onbank (Fig. 10a). This is consistent with release of the internal solibore from the shelfbreak formation region when the tide turns. This time difference gets longer as the surface float moves farther onbank. When the float and drifter are relatively close together, an estimate of the internal solibore propagation speed can be made by using the positions of the float when the internal solibore passes by at 173.625 (Fig. 7) and of the drifter when the same solibore passes by at 173.8 (Fig. 10b). This yields an propagation speed of $0.4 \mathrm{~m} \mathrm{~s}^{-1}$, again consistent with estimates above.

\section{3) ISOTHERMAL REBOUND}

After descending to its target density, the float rises at nearly constant temperature to a depth of $50 \mathrm{~m}$ by about day 173.45 (gray vertical bar in Fig. 7). This isothermal rise is a combination of the rebound of the density surface after the passage of the internal tide as mentioned above plus along-isopycnal upwelling at the foot of the shelfbreak front. Vertical sections of density (Fig. 8a) and temperature (Fig. 9a) show the float's position during this isothermal upwelling. The average vertical velocity during this time is $1.4 \times 10^{-3} \mathrm{~m} \mathrm{~s}^{-1}$ or $124 \mathrm{~m} \mathrm{day}^{-1}$. That this is too large for just along- 


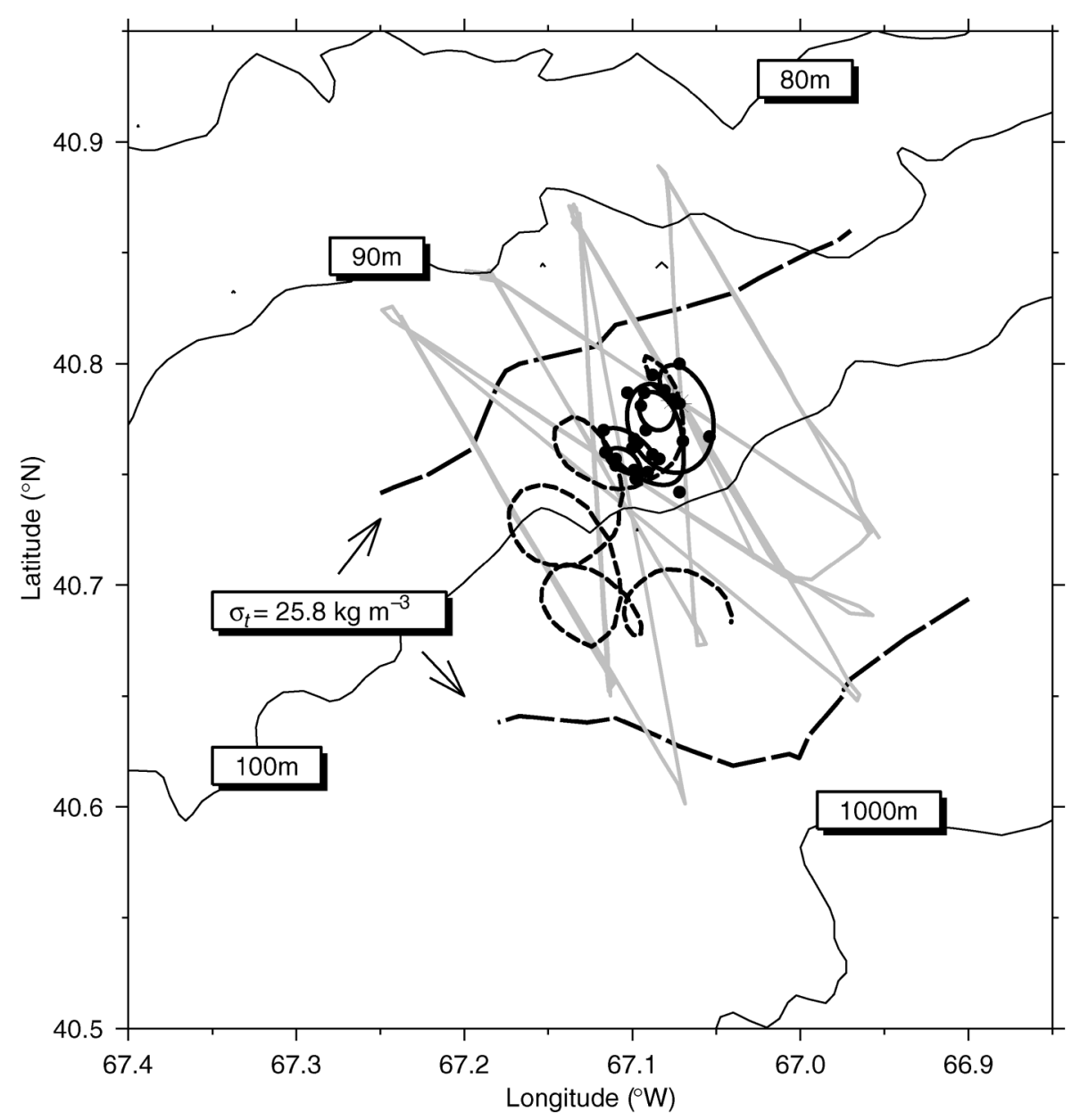

FIG. 14. Trajectories of a subsurface COOL float (thick solid curve and symbols) and a surface drifter (thick, short-dashed curve) from 25 to 28 Jun 1999. The continuous float trajectory is from a model fit (see text) to the float locations. The orientation of the shelfbreak front $\left(25.8 \mathrm{~kg} \mathrm{~m}^{-3}\right.$ at 55 $\mathrm{m}$ ) is indicated by a thick, long-dashed curve. SeaSoar sampling and acoustic tracking were done along the butterfly patterns (gray curves), which were shifted westward as the float and drifter were advected with the mean flow. Isobaths are in meters.

isopycnal upwelling can be discerned by noting that the float moves about $3.3 \mathrm{~km}$ across the front in the half day since launch (Fig. 6) and that the $25.8 \mathrm{~kg} \mathrm{~m}^{-3}$ isopycnal slope is $3.4 \times 10^{-3}$. This implies a vertical velocity of $2.6 \times 10^{-4} \mathrm{~m} \mathrm{~s}^{-1}$ or $22 \mathrm{~m} \mathrm{day}^{-1}$, consistent with our mean estimates made earlier.

The cycle repeats as the float descends in the internal tide solibore at day 173.65 then rises (day 173.7174.025) because of isothermal rebound of the pycnocline and along-isopycnal upwelling. Note the similarity of the float pressure trace in time in Fig. 7a to the spatial structure of the $25.1-25.7 \mathrm{~kg} \mathrm{~m}^{-3}$ isopycnals in Fig. 3c. A third period of isothermal rise (day 174.25-174.4) is shorter than the previous two. A final period of weaker isothermal rise occurs from day 174.8 to 175.0 , followed by an isothermal, nearly constant pressure period (175.0-175.2).

\section{4) AlONG-ISOPYCNAL DIFFUSION}

Near the end of the second period of isopycnal rebound (at day 174.05), the float warms again by about $2^{\circ} \mathrm{C}$. During this time the float does not record a significant prolonged negative diapycnal velocity. However, the float is in a region of a strong along-isopycnal temperature gradient (Fig. 9c) and so could warm by along-isopycnal diffusion. An estimate of horizontal diffusivity may be made using the SeaSoar-derived alongisopycnal temperature gradient at the float's location during the warming (Fig. 9c). Using $\Delta T / \Delta t=3.6 \times$ $10^{-4}{ }^{\circ} \mathrm{C} \mathrm{s}^{-1}$ and $\partial^{2} T / \partial y^{2}=1-2\left(\times 10^{-6}{ }^{\circ} \mathrm{C}^{2} \mathrm{~m}^{-2}\right)$ suggests that the horizontal diffusivity is on the order of $100 \mathrm{~m}^{2} \mathrm{~s}^{-1}$. This horizontal diffusivity estimate has a large uncertainty given the difficulty of estimating the along-isopycnal second derivative of temperature. 

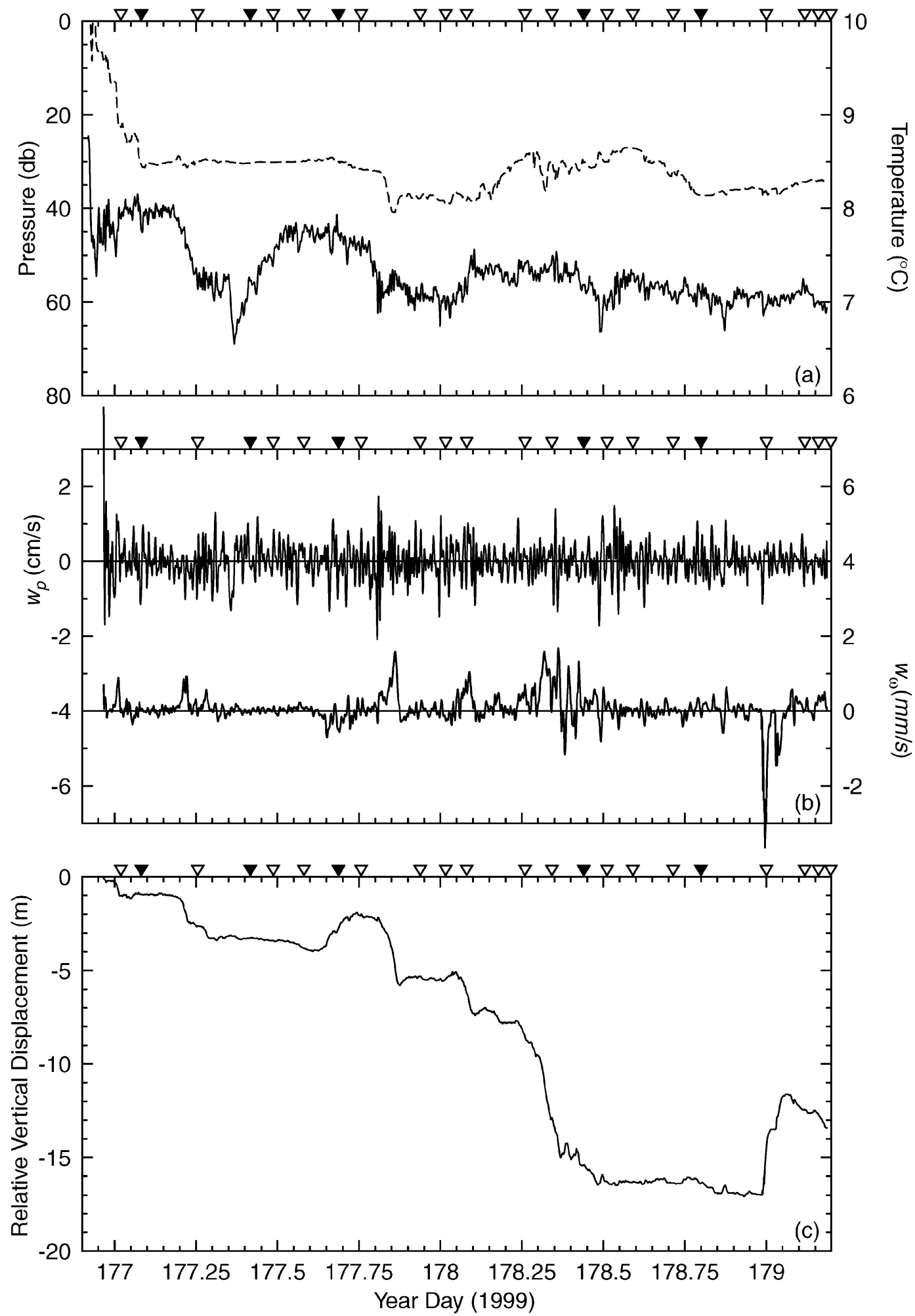

FIG. 15. As in Fig. 7 but for the subsurface COOL float tracked from 2207 UTC 25 Jun to 0546 UTC 28 Jun 1999. 

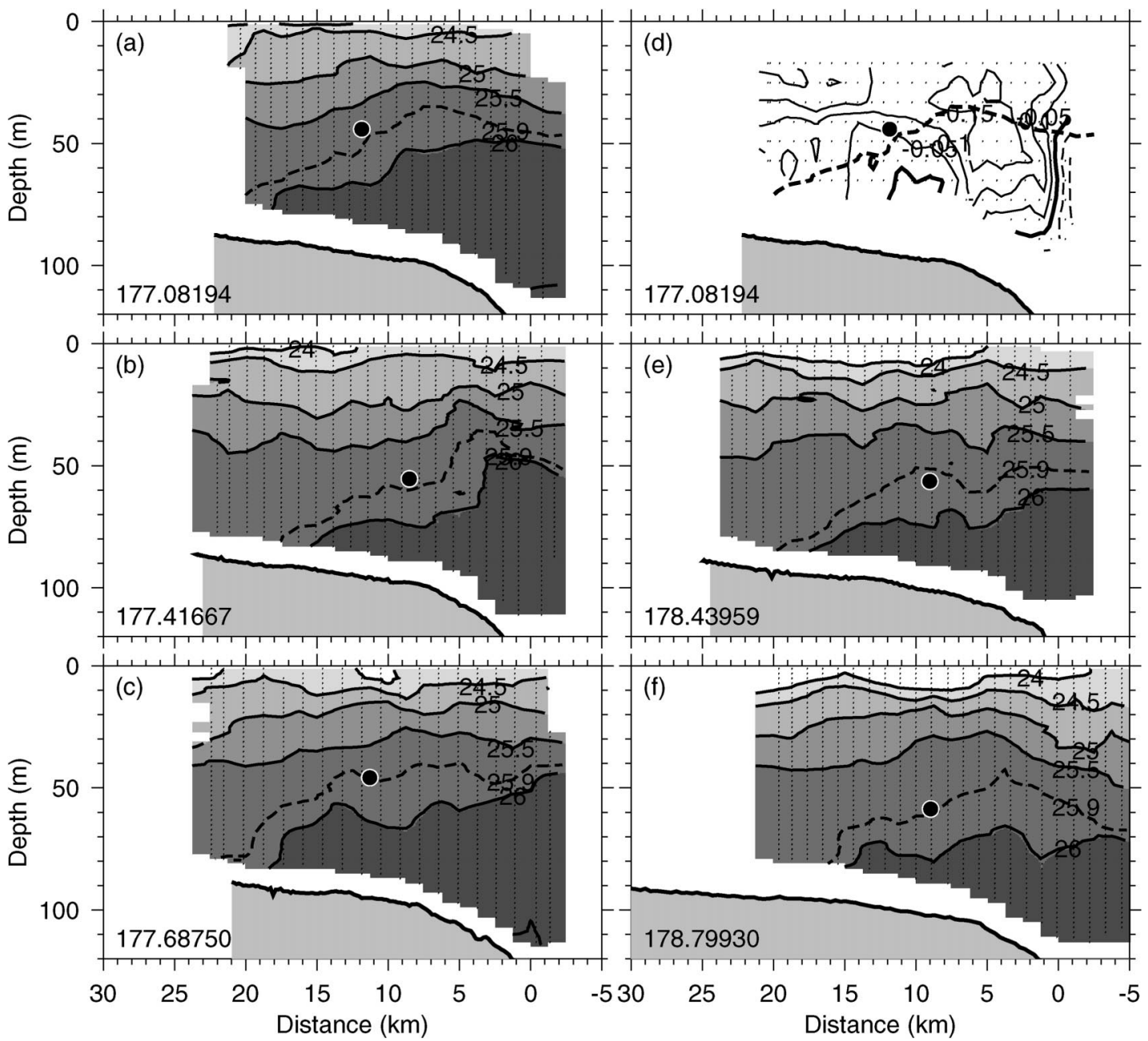

FIG. 16. (a)-(c), (e)-(f) Vertical sections of density $\left(\mathrm{kg} \mathrm{m}^{-3}\right)$ at selected subsurface float fix times. (d) Vertical section of along-bank velocity from the same time period as in (a) (contour interval $0.05 \mathrm{~m} \mathrm{~s}^{-1}$ ) with negative values (solid contours) toward $240^{\circ}$ true, i.e., southwestward. The float positions are indicated by black filled circles where the size of the circle roughly indicates the error in positioning. The $25.9 \mathrm{~kg} \mathrm{~m}^{-3}$ density contour is dashed.

\section{5) Diapycnal Velocity}

Near day 173.55, the float records a rise in temperature accompanied by a period of significant diapycnal velocity downward past the float (Fig. 7b). The water in which the float was located has undergone heating via a diapycnal flux in the presence of a diapycnal temperature gradient as evident in a vertical section of temperature from this time (Fig. 9b). By integrating $w_{\omega}$ over time, the float is displaced about $13 \mathrm{~m}$ relative to the water in which it was released during this diapycnal mixing event (Fig. 7c).

The diapycnal warming event from day 173.47 to 173.55 (Fig. 11) may be examined further in terms of a one-dimensional heat balance. An estimate of the potential influence of horizontal diffusion will be made following this calculation. Since the float is isopycnal, the time rate-of-change of temperature measured by the float should balance the diapycnal velocity times the temperature gradient

$$
\frac{D T}{D t}=-w_{\omega} \frac{\partial T}{\partial z} .
$$

From (1) an expression for the diapycnal velocity is

$$
w_{\omega}=-\frac{D T}{D t} / \frac{\partial T}{\partial z} .
$$

The float heats up by $2.6^{\circ} \mathrm{C}$ from 173.53 to 173.55 , an interval of $1728 \mathrm{~s}$ (Fig. 11a). From the closest SeaSoar profile to the float's location, $\partial T / \partial z=0.59^{\circ} \mathrm{C} \mathrm{m}^{-1}$ in the depth range $40-45 \mathrm{~m}$ (Fig. 12). The depth range of the mean density plus and minus one standard deviation $(25.84 \pm 0.10)$ is $37-43 \mathrm{~m}$. Calculating $w_{\omega}$ from (2) yields an estimate of $-2.6 \times 10^{-3} \mathrm{~m} \mathrm{~s}^{-1}$ or $-2.6 \mathrm{~mm}$ $\mathrm{s}^{-1}$. This is close to the float's average measured $w_{\omega}$ 


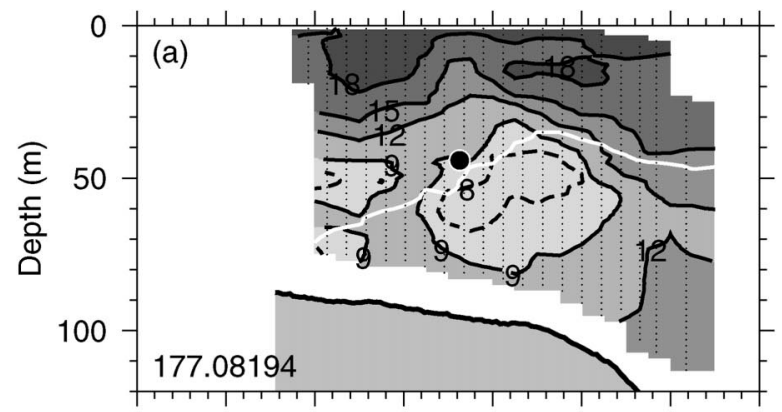

FIG. 17. Vertical sections of temperature $\left({ }^{\circ} \mathrm{C}\right)$ at selected subsurface float fix times. The float positions are indicated by black filled circles where the size of the circle roughly indicates the error in positioning. The $25.9 \mathrm{~kg} \mathrm{~m}^{-3}$ density contour is the white curve.
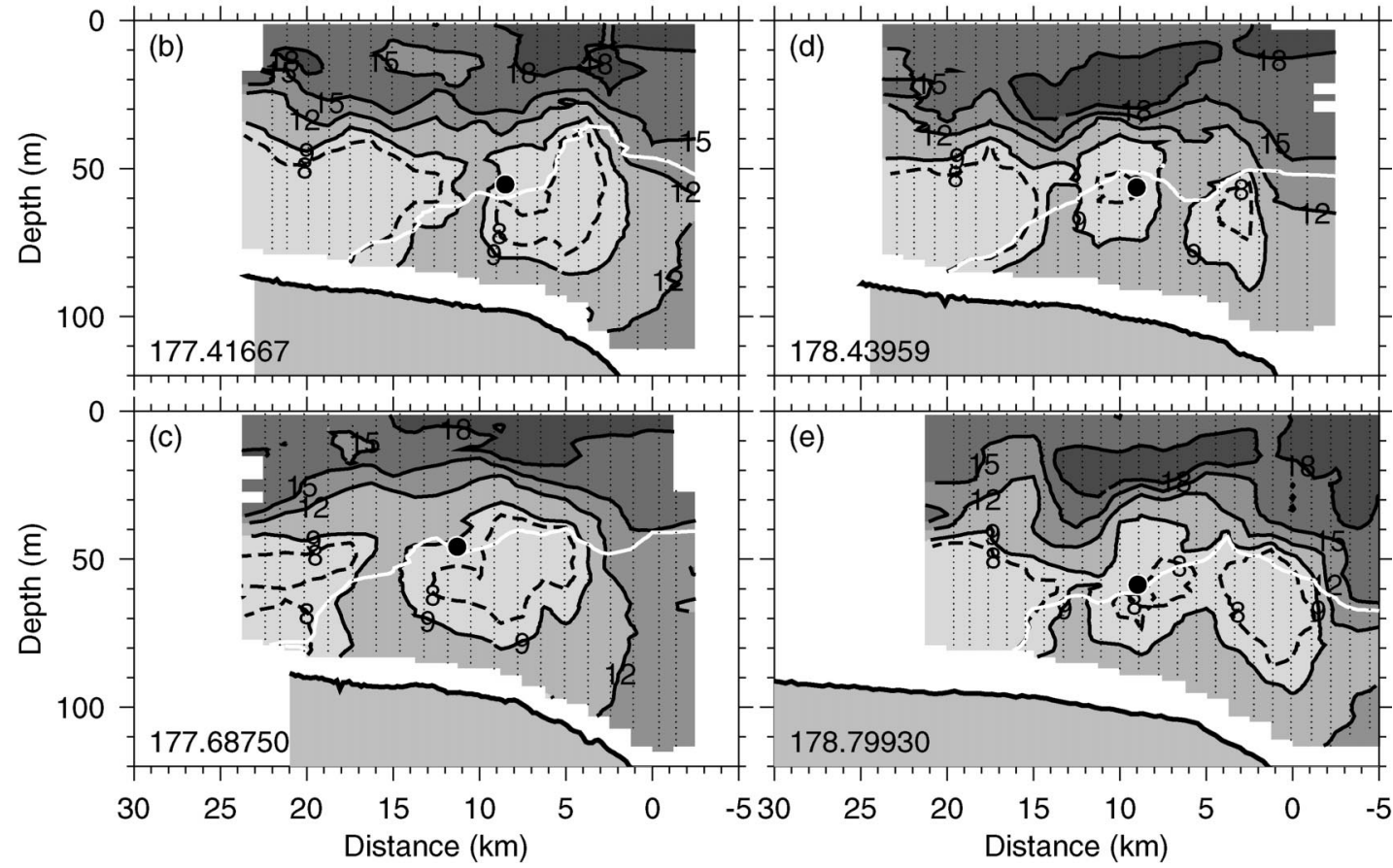

during this isopycnal warming event (173.47-173.55) (Fig. 11b). Given the uncertainty in estimating $\partial T / \partial z$ from a nearby SeaSoar profile, we conclude that the measured $w_{\omega}$ is consistent with the physics described by (1).

The float measures a smaller increase in temperature near the beginning of the diapycnal event (173.47173.49), but then remains isothermal near $9^{\circ} \mathrm{C}$ even in the presence of nonzero measured $w_{\omega}$ from 173.49 to 173.53. The SeaSoar measurements do not have sufficient horizontal resolution to resolve the temperature gradients to fine enough scale to apply (1) continuously to the float record. However, the lack of temperature change during this period is likely due to the absence of a diapycnal temperature gradient at this temperature (Fig. 12). This cusp in the vertical profile of temperature results from the presence of the cold pool on the outer shelf (Fig. 9).

Returning to the one-dimensional balance used in estimating $w_{\omega}$ from (1), a temperature change of $3.6 \times$ $10^{-4}{ }^{\circ} \mathrm{C} \mathrm{s}^{-1}$ due to horizontal diffusion-our estimate earlier of along-isopycnal diffusion in the frontal re- gion-represents $20 \%$ of the observed $1.5 \times 10^{-3}{ }^{\circ} \mathrm{C}$ $\mathrm{s}^{-1}$ temperature change during this event. Thus, there is at least a $20 \%$ error in estimates of $w_{\omega}$ based on assuming a one-dimensional balance.

Since the isopycnal float makes a direct measurement of the flow past the float due to diapycnal mixing, we can estimate $\kappa_{T}\left(\mathrm{~m}^{2} \mathrm{~s}^{-1}\right)$, the diapycnal thermal diffusivity as follows. Assuming again a one-dimensional heat balance following the float

$$
\frac{D T}{D t}=\frac{\partial}{\partial z}\left(\kappa_{T} \frac{\partial T}{\partial z}\right),
$$

equating (1) and (3), assuming that $w_{\omega}$ is independent of $z$, and integrating between $z_{1}$ and $z_{2}$ yields

$$
\kappa_{T}=\frac{-w_{\omega}\left[T\left(z_{1}\right)-T\left(z_{2}\right)\right]}{\left[\frac{\partial T}{\partial z}\left(z_{1}\right)-\frac{\partial T}{\partial z}\left(z_{2}\right)\right]} .
$$

For the diapycnal warming event during the first float deployment (Figs. 11 and 12), using values of $w_{\omega}=$ 

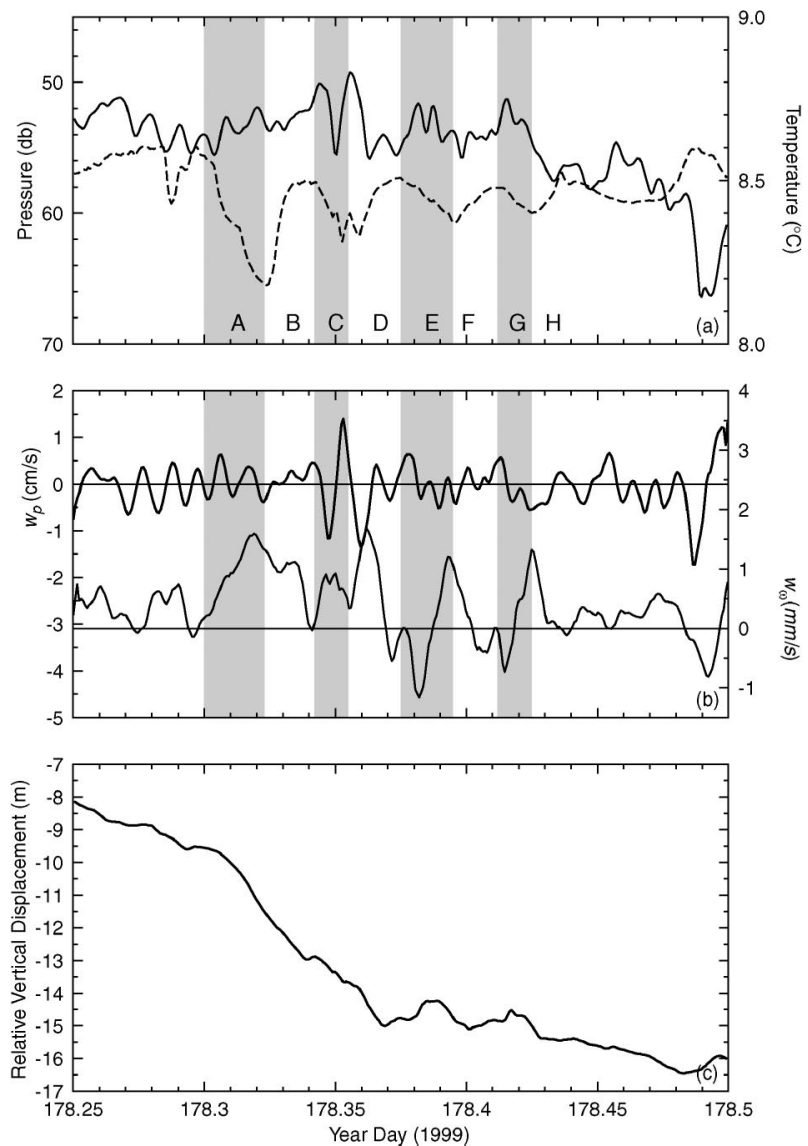

FIG. 18. As in Fig. 7 but for the subsurface COOL float tracked from 0600 to 1200 UTC 27 Jun 1999. Gray vertical bars denote periods when the float detected cooling; events $A-G$ are described in the text.

$-2.6 \times 10^{-3} \mathrm{~m} \mathrm{~s}^{-1},\left[T\left(z_{1}\right)-T\left(z_{2}\right)\right]=2.6^{\circ} \mathrm{C}$, and $\partial T /$ $\partial z=0.86$ and $0.29{ }^{\circ} \mathrm{C} \mathrm{m}^{-1}$ at $z_{1}=42 \mathrm{~m}$ and $z_{2}=46$ $\mathrm{m}$, respectively, (see Fig. 12) gives $\kappa_{T}=1.2 \times 10^{-2}$ $\mathrm{m}^{2} \mathrm{~s}^{-1}$.

Another period of warming near day 174.525 after isothermal rebound is again accompanied by a negative diapycnal velocity (heat flux down from above). A vertical section just prior to this warming shows the float position relative to the vertical temperature gradient (Figs. 8e and 9e).

\section{c. Second subsurface float deployment}

A second deployment of a subsurface float and drogued surface drifter was carried out from 25-28 June 1999. During this period the shelfbreak front rose to about $40 \mathrm{~m}$ starting from around $70 \mathrm{~m}$ near the foot on the bank (Fig. 13). In contrast to the first float deployment period though, the front deepened again to the south (Fig. 13). This doming of the isopycnals and a more convoluted front (cf. Figs. 5 and 13) are likely due to the mesoscale variability introduced by the presence of a warm core ring offshore. The subsurface float

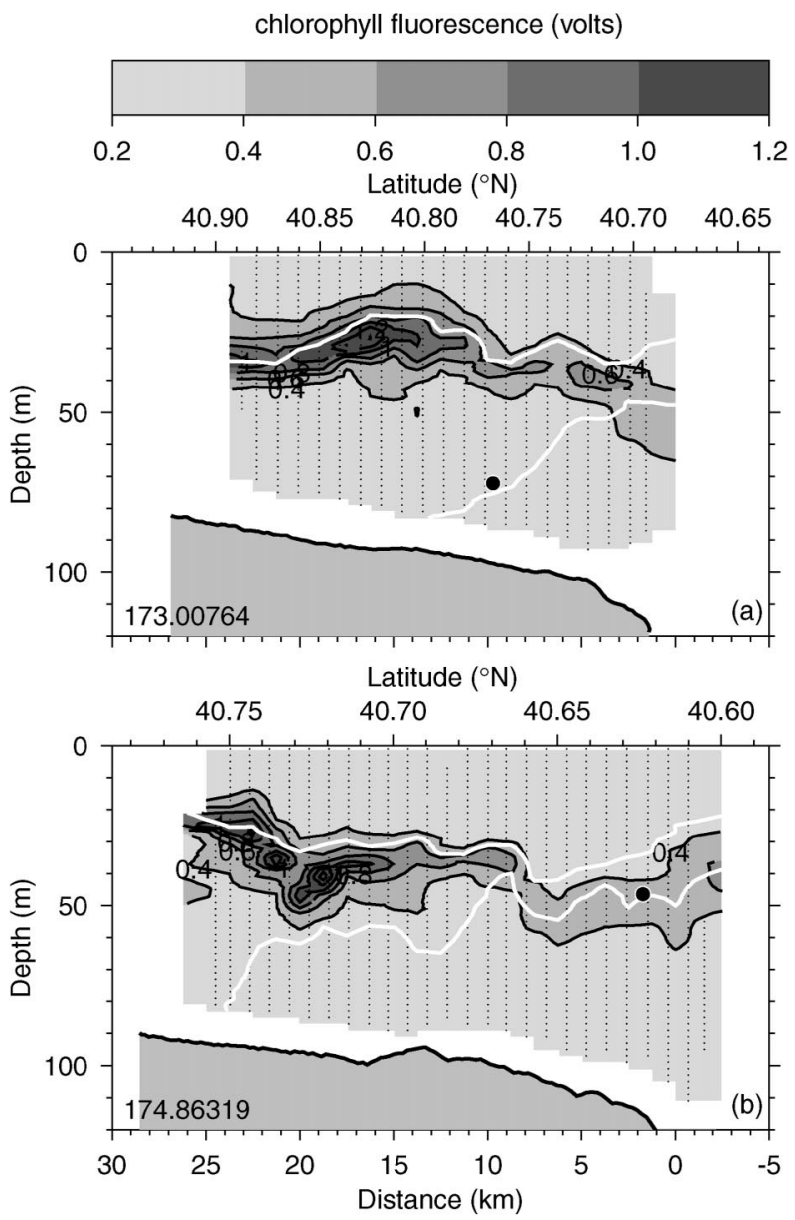

FIG. 19. Vertical sections of chlorophyll fluorescence (V) near the (a) launch and (b) recovery times (indicated in lower-left corner of each panel) of the subsurface float. The thick white curves are the 25.2 and $25.8 \mathrm{~kg} \mathrm{~m}^{-3}$ density contours.

was advected by the semidiurnal tide, but moved less than $5 \mathrm{~km}$ from its release point (Fig. 14). The surface drogued drifter also moved with the tide, but was advected initially to the southwest before moving offbank and eastward. This cyclonic movement is consistent with the observed ridge in the density field (Fig. 13) via geostrophic balance.

A time series from the float shows an overall descent from around $40 \mathrm{~m}$ at deployment to $60 \mathrm{~m}$ at recovery for a net $10 \mathrm{~m} \mathrm{day}^{-1}$ downwelling (Fig. 15). Cross-bank sections of density advected with the tide to the time of selected float fixes show that isopycnals in the shelfbreak front bend down on the offbank end of the sections (Fig. 16). The float rides on top of cold pool except at 178.43959 (Fig. 17d) when the float is located at a local temperature minimum such that warm water lies both above and below. This section is from just after the cooling and warming events described below which rely on the presence of an inflection point in the vertical profile of temperature.

A comparison of the float record with nearby SeaSoar 
profiles reveals that this float was also isopycnal within the error of the estimates (PHRF). Over 19 comparative points, the mean (standard deviation) is $25.88(0.05) \mathrm{kg}$ $\mathrm{m}^{-3}$ versus $25.84(0.10) \mathrm{kg} \mathrm{m}^{-3}$ for the first release.

Signatures of internal tide solibores are present (e.g., 177.35, Fig. 15), but are not as evident as during the first float deployment because the background density field is more complex. This complexity affects both formation and propagation of the internal tide. Note, however, that during the solibore passage at 177.35 downward velocities reach $-0.01 \mathrm{~m} \mathrm{~s}^{-1}$, the float remains isothermal and there is relatively little measured flow past the float. As during solibore passage during the first deployment, this response is essentially adiabatic. Evidence for an internal tide solibore is present at $5 \mathrm{~km}$ on-bank from the shelf break at 178.43959 (Fig. 16e).

Over the entire record, water moves up past the float such that the float ends up about $13 \mathrm{~m}$ below the water in which it was originally released (Fig. 15c). The overall movement of water past the float occurs in a few periods of significant positive diapycnal velocity, for example, 177.85, 178.05, and 178.3-178.5. Cooling occurs during the first and last of these events, so colder water must lie below the float. In fact, the float is riding on top of the cold pool (Fig. 17).

The event from 178.3 to 178.5 accounts for about half of the total relative vertical displacement of water past the float (Fig. 18). Cooling occurs at the start of this event (178.3-178.323; gray vertical bar labeled A in Fig. 18) when the float lies above the cold pool. A cooling of $0.42^{\circ} \mathrm{C}$ in $2160 \mathrm{~s}$ in the presence of a vertical temperature gradient from a nearby SeaSoar profile (not shown) of $0.12^{\circ} \mathrm{C} \mathrm{m}^{-1}$ and using (2) yields a diapycnal velocity of $1.62 \times 10^{-3} \mathrm{~m} \mathrm{~s}^{-1}$, consistent with the observed motion past the float. Immediately after the float cools because of water moving up from below, the float warms even in the presence of continued motion of water from below (B: 178.323-178.342). This is consistent with the existence of warm water below the float, i.e. below the cold pool (Fig. 17d). The float repeats this behavior once more, cooling (C: 178.342-178.355) then warming (D: 178.355-178.375) with water movement up past the float in the presence of the inflection in the $\partial T / \partial z$ profile. Then the float undergoes two cycles of downward movement of water past the float accompanied by cooling $(\mathrm{E}, \mathrm{G})$, followed by upward movement of water past the float and warming $(\mathrm{F}, \mathrm{H})$. This pattern is a consequence of the float now being located beneath the $\partial T / \partial z$ inflection point so that colder water lies above and warmer below.

\section{Discussion}

The directly measured mean along-isopycnal vertical velocity of $17.5 \mathrm{~m} \mathrm{day}^{-1}$ within the shelfbreak front on the southern flank of Georges Bank is qualitatively consistent with, but larger than, model predictions for secondary circulation near a shelfbreak front (Gawarkiew- icz and Chapman 1992; Chapman and Lentz 1994). However, quantitative estimates of the strength of the secondary flow in the models are sensitive to the parameterization of vertical mixing (Chapman 2002). The measured along-isopycnal upwelling velocity during the first semidiurnal period of the float mission, $31.0 \mathrm{~m}$ day $^{-1}$, is also in excess of previous estimates of 4-11 $\mathrm{m}$ day $^{-1}$ from a purposeful dye release (Houghton and Visbeck 1998) and through analysis of the distribution of suspended particles and by integrating horizontal velocity convergence (Barth et al. 1998). Both these previous studies estimated vertical velocities within 30-40 $\mathrm{m}$ of the bottom and invoked convergence in the bottom boundary layer for their origin. The subsurface float measurements during the first semidiurnal period of the float mission extend up to about $55 \mathrm{~m}$ above the bottom. Models predict maximum vertical velocities higher in the water column, above the bottom boundary layer, consistent with the float results. The vertical velocity estimate of $23 \mathrm{~m} \mathrm{day}^{-1}$ from integration of the continuity equation using measured cross-stream velocities (Pickart 2000) falls within the range (9.5-31.0 $\mathrm{m} \mathrm{day}^{-1}$ ) measured here. We note that the size of the vertical velocity is also sensitive to the slope of the shelfbreak front, which may differ in each of these realizations.

The upwelling of nutrient-rich water along isopycnals from near the bottom up into the euphotic zone could fuel the high phytoplankton biomass observed in association with the shelfbreak front (Marra et al. 1990). For the 22-24 June 1999 deployment, the float begins in a region of low chlorophyll fluorescence near the foot of the shelfbreak front and then rises into a region of higher fluorescence where the shelfbreak front joins the 20-30-m-deep pycnocline (Fig. 19).

Measured diapycnal velocities of up to $3 \times 10^{-3} \mathrm{~m}$ $\mathrm{s}^{-1}$ occur along the shelfbreak front separating cold, fresh shelf water from warm, salty slope water. These velocities are three orders of magnitude greater than the diathermal velocities inferred from dye patch evolution in the stratified region just above the bottom boundary layer near the foot of the shelfbreak front (Houghton and Visbeck 1998). Much of this discrepancy is due to the fact that the dye-based estimate is an integral over several days and several kilometers spatially, while the float-based measurement is essentially an instantaneous point measurement. Using the total relative displacement of water past the float for each 2-day deployment (Figs. 7c and 15c) yields an average diapycnal velocity of 4-8 ( $\left.\times 10^{-5} \mathrm{~m} \mathrm{~s}^{-1}\right)$.

The strong mixing in this approximately 2 -h event yields diffusivites about three orders of magnitude greater than longer time-averaged open ocean values, indicative of strong mixing events that can occur in the coastal ocean (e.g., Horne et al. 1996; Gregg 1998). Estimates of time-averaged vertical diffusivity from a dye release experiment over 2.5-5 days in stratified coastal water away from the shelfbreak front are also small: 0.4-3.0 $\left(\times 10^{-5} \mathrm{~m}^{2} \mathrm{~s}^{-1}\right)$ (Sundermeyer and Ledwell 2001). The 
need for continuous estimates of the vertical temperature gradient along the float track precludes an estimate of a longer time-average diapycnal thermal diffusivity from the present experiment. The float-derived estimate of $\kappa_{T}$ may also be compared with values from the shelfbreak front region using a towed microstructure instrument (Dillon et al. 2003) where vertical temperature variance is used to estimate $\kappa_{T}$ :

$$
\kappa_{T}=3 D \overline{\left(\frac{\partial T^{\prime}}{\partial z}\right)^{2}} /\left(\overline{\frac{\partial T}{\partial z}}\right)^{2},
$$

where $D=1.4 \times 10^{-7} \mathrm{~m}^{2} \mathrm{~s}^{-1}$ is the molecular diffusivity. In a May 1997 section across the shelfbreak front along $70.5^{\circ} \mathrm{W}$ to the west of Georges Bank, Dillon et al. (2003) reported diffusivities as large as $1 \times 10^{-3} \mathrm{~m}^{2}$ $\mathrm{s}^{-1}$ and sometimes larger.

\section{Summary and conclusions}

In this paper, direct observations of upwelling along a shelfbreak front using a Lagrangian subsurface float in combination with high-spatial-resolution hydrographic and velocity mapping are reported. The region of upwelling extends from the foot of the shelfbreak front up to $60 \mathrm{~m}$ above the bottom, well above the bottom boundary layer. The average along-isopycnal vertical velocity is estimated at $17.5 \mathrm{~m} \mathrm{day}^{-1}$ so that a water parcel could transit to the sea surface in about 5 days. Mesoscale variability in the shelfbreak front and jet evidently disrupts this secondary flow.

Intense mixing was observed in the shelfbreak front at the boundary between cold, fresh shelf bottom water (the cold pool) and warm, salty slope water. Diapycnal velocities of up to $3 \times 10^{-3} \mathrm{~m} \mathrm{~s}^{-1}$, both up and down past the isopycnal float, were measured. By equating this diapycnal velocity with a diapycnal thermal diffusivity, an estimate of $10^{-2} \mathrm{~m}^{2} \mathrm{~s}^{-1}$ was found for these intense, relatively short-lived $(\leq 2 \mathrm{~h})$ events near the shelfbreak front. This value is three orders of magnitude greater than longer time-averaged diffusivities measured in the open ocean and in stratified flow over the continental shelf, indicative of the high level of mixing in episodic events near frontal boundaries in the coastal ocean.

The combination of rapid, three-dimensional hydrographic and bio-optical mapping with a towed undulating vehicle, measurement of subsurface currents with shipboard acoustic Doppler current profiling, and deployment of a Lagrangian subsurface isopycnal float capable of measuring diapycnal velocity allows the details of complex coastal phenomenon to be elucidated. This suite of tools has obvious application in other regions of significant vertical motion and mixing (e.g., a coastal upwelling front). It would also be interesting to explore along-isopycnal diffusion and dispersion using clusters of these isopycnal floats.
Acknowledgments. We thank the Oregon State University Marine Technicians, M. Willis and L. Fayler, for the successful SeaSoar operations and R. O'Malley for SeaSoar data acquisition and processing. We gratefully acknowledge the officers and crew of the R/V Oceanus for their skillful efforts at sea. Thanks to S. Fontana for help in collecting and processing the ADCP data. We also appreciate the assistance of M. Prater and J. Fontaine for the preparation of the COOL floats and for recovering data from a slightly flooded float. We thank D. Gifford and K. Wishner for providing the ADCP velocity data from R/V Endeavor cruise 325 and R. Schlitz for providing moored velocity data, both of which were used in our tidal velocity analysis. L. Huey, then an undergraduate student at Grambling State University, helped with the analysis of the temperature time series shown in Fig. 10. Thanks to T. Boyd for computing the theoretical mode-1, semidiurnal internal wave phase speeds. J. Bisagni generously provided the satellite sea surface temperature image. Support from National Science Foundation Grants OCE-9806650 and OCE-9813641 is gratefully acknowledged. Additional support for JAB during the analysis phase was provided by NSF Grants OCE-9907854 and OCE-0001035 and for $\mathrm{DH}$ from the State of Rhode Island and Providence Plantations.

\section{REFERENCES}

Apel, J. R., H. M. Byrne, J. R. Proni, and R. L. Charnell, 1975: Observations of oceanic internal and surface waves from the Earth Resources Technology Satellite. J. Geophys. Res., 80, 865881.

Baines, P. G., 1986: Internal tides, internal waves, and near-inertial motions. Baroclinic Processes on Continental Shelves, C. N. K. Mooers, Ed., Coastal and Estuarine Sciences, Vol. 2, Amer. Geophys. Union, 19-32.

Barth, J. A., D. Bogucki, S. D. Pierce, and P. M. Kosro, 1998: Secondary circulation associated with a shelfbreak front. Geophys. Res. Lett., 25, 2761-2764.

_, R. O'Malley, and A. Erofeev, cited 2000a: SeaSoar CTD, chlorophyll fluorescence and light transmission observations during the GLOBEC Georges Bank cruises: R/V Oceanus cruises from 28 March to 12 April and 14 June to 1 July 1999. [Available online at http://diana.coas.oregonstate.edu/globec/globecweb.]

_ _ S. D. Pierce, and R. L. Smith, 2000b: A separating coastal upwelling jet at Cape Blanco, Oregon, and its connection to the California Current System. Deep-Sea Res., 47, 783-810.

Bleck, R., C. Rooth, D. Hu, and L. T. Smith, 1992: Salinity-driven thermocline transients in a wind- and thermohaline-forced isopycnic coordinate model of the North Atlantic. J. Phys. Oceanogr., 22, 1486-1505.

Boebel, O., K. L. Schultz Tokos, and W. Zenk, 1995: Calculation of salinity from neutrally buoyant RAFOS floats. J. Atmos. Oceanic Technol., 12, 923-934.

Candela, J., R. C. Beardsley, and R. Limeburner, 1992: Separation of tidal and subtidal currents in ship-mounted acoustic Doppler current profiler observations. J. Geophys. Res., 97, 769-788.

Chapman, D. C., 2002: Sensitivity of a model shelfbreak front to the parameterization of vertical mixing. J. Phys. Oceanogr., 32, 3291-3298.

, and S. J. Lentz, 1994: Trapping of a coastal density front by the bottom boundary layer. J. Phys. Oceanogr., 24, 1464-1479.

Dale, A. C., D. S. Ullman, J. A. Barth, and D. Hebert, 2003: The 
front on the northern flank of Georges Bank in spring. Part I: Tidal and subtidal variability. J. Geophys. Res., 108, 8009, doi: 10.1029/2002JC001327.

D’Asaro, E. A., 2003: Performance of autonomous Lagrangian floats. J. Atmos. Oceanic Technol., 20, 896-911.

Dillon, T. M., J. A. Barth, A. Y. Erofeev, G. H. May, and H. W. Wijesekera, 2003: MicroSoar: A new instrument for measuring microscale turbulence from rapidly moving submerged platforms. J. Atmos. Oceanic Technol., 20, 1671-1684.

Gawarkiewicz, G., and D. C. Chapman, 1992: The role of stratification in the formation and maintenance of shelfbreak fronts. $J$. Phys. Oceanogr., 22, 753-772.

Gregg, M. C., 1998: Estimation and geography of diapycnal mixing in the stratified ocean. Phys. Processes Lakes Oceans, 54, 305338 .

Hebert, D., M. Prater, J. Fontaine, and T. Rossby, 1997: Results from the test deployments of the COastal Ocean Lagrangian (COOL) float. GSO Tech. Rep. 97-2, University of Rhode Island, 27 pp.

_ J. J. A. Barth, D. S. Ullman, and S. Fontana, 1999: Cruise report R/V Oceanus cruise 343 to Georges Bank, 14 June to 1 July 1999. US GLOBEC NW Atlantic/Georges Bank Study, 28 pp.

Henyey, F. S., and A. Hoering, 1997: Energetics of borelike interna waves. J. Geophys. Res., 102, 3323-3330.

Horne, E. P. W., J. W. Loder, C. E. Naime, and N. S. Oakey, 1996 Turbulence dissipation rates and nitrate supply in the upper water column on Georges Bank. Deep-Sea Res., 43B, 1683-1712.

Houghton, R. W., and M. Visbeck, 1998: Upwelling and convergence in the Middle Atlantic Bight shelfbreak front. Geophys. Res. Lett., 25, 2765-2768.

Lamb, K. G., 1994: Numerical experiments of internal wave generation by strong tidal flow across a finite amplitude bank edge. J. Geophys. Res., 99, 843-864.

Levine, M., and T. Boyd, 1998: Nonlinear internal wave observations on the continental shelf. The 1998 WHOI/IOS/ONR Interna Solitary Wave Workshop: Contributed Papers, Woods Hole Oceanographic Institute Tech. Rep. WHOI-99-07, 101-106.
Liu, A. K., 1988: Analysis of nonlinear internal waves in the New York Bight. J. Geophys. Res., 93, 12 317-12 329.

Loder, J. W., D. Brickman, and E. P. W. Horne, 1992: Detailed structure of currents and hydrography on the northern side of Georges Bank. J. Geophys. Res., 97, 14 331-14 351

Marra, J., R. W. Houghton, and C. Garside, 1990: Phytoplankton growth at the shelf-break front in the Middle Atlantic Bight. $J$. Mar. Res., 48, 851-868.

McDougall, T. J., 1984: The relative roles of diapycnal and isopycnal mixing on subsurface water mass conversion. J. Phys. Oceanogr., 14, 1577-1589.

Pickart, R. S., 2000: Bottom boundary layer structure and detachment in the shelfbreak jet of the Middle Atlantic Bight. J. Phys. Oceanogr., 30, 2668-2686.

Pollard, R. T., 1986: Frontal surveys with a towed profiling conductivity/temperature/depth measurement package (SeaSoar). $\mathrm{Na}$ ture, 323, 433-435.

Rajamony, J., S. Peterson, J. Fontaine, D. Hebert, T. Rossby, and M. Prater, 1996: Vane design for the Coastal Ocean Lagrangian (COOL) float. GSO Tech. Rep. 96-8, University of Rhode Island, 24 pp.

Rossby, T., J. Fontaine, and E. C. Carter Jr., 1994: The f/h floatMeasuring stretching vorticity directly. Deep-Sea Res., 41, 975-992.

Sundermeyer, M. A., and J. R. Ledwell, 2001: Lateral dispersion over the continental shelf: Analysis of dye release experiments. $J$. Geophys. Res., 106, 9603-9621.

Ullman, D., S. Fontana, and D. Hebert, 2000: U.S. GLOBEC: ADCP observations on Georges Bank during RV Oceanus cruises 340 (28 March to 12 April 1999) and 343 (14 June to 1 July 1999). GSO Tech. Rep. 00-1, University of Rhode Island, 219 pp.

, A. C. Dale, D. Hebert, and J. A. Barth, 2003: The front on the Northern Flank of Georges Bank in spring. Part II: Cross-frontal fluxes and mixing. J. Geophys. Res., 108, 8010, doi:10.1029/ 2002JC001328.

Voorhis, A. D., 1968: Measurements of vertical motion and the partition of energy in the New England slope water. Deep-Sea Res., 15, 599-608. 